NBER WORKING PAPER SERIES

\title{
NATIONALISM AND ECONOMIC EXCHANGE: EVIDENCE FROM SHOCKS TO SINO-JAPANESE RELATIONS
}

\author{
Raymond Fisman \\ Yasushi Hamao \\ Yongxiang Wang
}

Working Paper 20089

http://www.nber.org/papers/w20089

\author{
NATIONAL BUREAU OF ECONOMIC RESEARCH \\ 1050 Massachusetts Avenue \\ Cambridge, MA 02138 \\ May 2014
}

We would also like to thank David Hirshleifer, two anonymous referees, seminar participants at the 2012 NBER Chinese Economy Working Group Conference, the 2012 Conference on Financial Economics and Accounting, the 2012 California Corporate Finance Conference, the 2013 NBER Japan Working Group Conference, University of Southern California, as well as Amy Amici, Shiro Armstrong, William Christie, Christina Davis, Harry DeAngelo, Charles Horioka, Takeo Hoshi, Yasheng Huang, Takatoshi Ito, Yi Jiang, Takao Kato, Masahiro Kawai, John Matsusaka, Hugh Patrick, David Weinstein, Bernard Yeung, and Xiaoyun $\mathrm{Yu}$ for helpful comments and suggestions. Fisman would like to thank the Chazen Institute of International Business at Columbia Business School for support; Hamao would like to thank CIBER at Marshall School of Business, USC for support; and Wang would like to thank CIBER at Marshall School of Business, USC and China Institute at USC for support. Rong Xu, Kazuo Yamada, and Jane Zhao provided outstanding research assistance. The views expressed herein are those of the authors and do not necessarily reflect the views of the National Bureau of Economic Research.

NBER working papers are circulated for discussion and comment purposes. They have not been peerreviewed or been subject to the review by the NBER Board of Directors that accompanies official NBER publications.

(C) 2014 by Raymond Fisman, Yasushi Hamao, and Yongxiang Wang. All rights reserved. Short sections of text, not to exceed two paragraphs, may be quoted without explicit permission provided that full credit, including $(\mathcal{C}$ notice, is given to the source. 
Nationalism and Economic Exchange: Evidence from Shocks to Sino-Japanese Relations Raymond Fisman, Yasushi Hamao, and Yongxiang Wang

NBER Working Paper No. 20089

May 2014

JEL No. F13,F51,G14,G15

\begin{abstract}
We study the impact of nationalism and interstate frictions on international economic relations by analyzing market reaction to adverse shocks to Sino-Japanese relations in 2005 and 2010. Japanese companies with high China exposure suffer relative declines during each event window; a symmetric effect is observed for Chinese companies with high Japanese exposure. The effect on Japanese companies is more pronounced for those operating in industries dominated by Chinese state-owned enterprises, while firms with high Chinese employment experience lower declines. These results emphasize the role of countries' economic and political institutions in mediating the impact of interstate frictions on firm-level outcomes.
\end{abstract}

Raymond Fisman

School of Business

Columbia University

622 Uris Hall

3022 Broadway

New York, NY 10027

and NBER

rf250@columbia.edu

Yasushi Hamao

University of Southern California

Marshall School of Business

3670 Trousdale Parkway, Bridge Hall 308

University of Southern California

Los Angeles, CA 90089-0804

hamao@usc.edu
Yongxiang Wang

Marshall School of Business

University of Southern California

Los Angeles, CA 90089

Yongxiang.Wang@marshall.usc.edu 
Beginning with Becker's (1957) seminal work on discrimination, researchers have incorporated non-pecuniary preferences into models to explain the breakdown of economic transactions across group boundaries. The economic effects of hostilities between countries or other distinct groups are potentially large and global in scale. This is indicated by, for example, Guiso, Sapienza, and Zingales (2009), which finds that aspects of culture like religion and historic conflict are correlated with cross-border flows of trade and investment. However, most prior work has focused on cross-sectional variation in trust and cultural distances between countries, raising concerns that omitted country-level factors could account for the correlation. Partly as a result, the causal relationship between interstate frictions and economic exchange remains a much-debated question (Hegre, Onea, and Russett 2010).

In this paper, we shed light on this relationship by examining the effects of the two recent incidents that sparked nationalist sentiments - and interstate hostilities -between China and Japan. By analyzing the stock market responses to these adverse shocks to relations between the two countries, we can credibly identify the expected economic impact of a shift in international relations on individual firms. ${ }^{1}$ Given our firm-level focus we may, in contrast to most prior studies, trace out the microeconomic impact of increased animosity between nations. Crucially, our firm-level approach also allows us to provide insights on

\footnotetext{
${ }^{1}$ The effect of such shocks to sentiment is ambiguous ex ante, as evidenced by media reports on the topic. For example, while a Wall Street Journal article reported that Japanese auto makers' sales in China plummeted in the wake of anti-Japanese protests (The Wall Street Journal: "Japanese Car Sales Plunge amid China Rage," October 9, 2012, by Chester Dawson and Yoshio Takahashi); another Wall Street Journal story just a few months later described the double-digit gains of major Japanese car makers in China as a result of "a boost from a calendar shift as well as the waning impact of a territorial dispute between Beijing and Tokyo." (The Wall Street Journal: "Lunar Holiday Shift Lifts Japanese Car Sales in China," February 04, 2013, by Rose $\mathrm{Yu})$.
} 
the mechanism through which nationalist sentiments and interstate frictions impact firm value: Is it the collective effect of individual investor and/or consumer animosity, or is it largely the result of diplomatic frictions between opposing governments? Our firm-level data, combined with our event study method, allow us to mitigate omitted variable concerns, as we also investigate the channels through which interstate conflicts affect abnormal event returns.

The events we consider are as follows. First, on April 5, 2005, the Japanese government reauthorized the use of a history textbook that, according to critics, whitewashed Japanese war crimes of World War II (see, for example, Weiss 2008). Hints of protest had taken place in earlier weeks, but the official announcement was followed by mass anti-Japan rallies across China, possibly coordinated by the Chinese government. We refer to this as the "Textbook Event" throughout the rest of this paper. The second episode we consider occurred on September 7, 2010, when a Chinese trawler collided with two Japanese coast guard vessels in disputed waters just off the Senkaku Islands, leading to the detention of the Chinese trawler captain by Japanese authorities. The "Senkaku Event" was followed by diplomatic posturing on both sides, and large-scale public protests in China as well as Japan. In China, both events triggered nationwide demonstrations against Japan on a scale that had not been seen since those at Tian'An Men Square in 1989.

Investors responded sharply in the wake of the Textbook Event: In April of 2005, the Nikkei 225 Index fell by about 6.1 percent while the Shanghai Composite declined by nearly 5.3 percent. By comparison, the S\&P 500 lost 1.4 percent of its value over the same period. More interestingly, in our main analysis we find that the market reactions for 
Japanese companies were highly sensitive to China exposure; for each percentage point increase in sales to China, cumulative abnormal returns (estimated using a standard Fama and French (1993) three-factor model) during April 5-28, 2005 fell by an additional 0.08 percent. That is, firms more dependent on economic relations with China were more adversely affected by an increase in Sino-Japan hostilities. We find a symmetric impact on Chinese firms.

Following the Senkaku collision, which was accompanied by more overt economic threats from China, neither the Nikkei nor the Shanghai Composite declined overall. We nonetheless find a large and significant impact of China exposure on event returns during the Senkaku Event window of September 7 - October 29, 2010 for Japanese firms, and also a negative effect of Japanese exports on Chinese firms' cumulative abnormal event returns (though the latter effect is not statistically significant).

We provide evidence that helps to adjudicate amongst explanations for the impact of China exposure on Japanese firms, using cross-sectional variation in company and industry attributes. We find that the vulnerability of Japanese firms with high sales to China is mediated by factors that, we argue, would make them susceptible to Chinese government intervention in a company's main line of business. Companies operating in industries dominated by state-owned enterprises (SOEs) are more sensitive to Sino-Japanese tensions, while those with high employment in China are relatively insulated from the effects of these interstate hostilities.

We argue that this is likely due to the fact that in SOE-dominated sectors, the government has greater incentive to intervene to benefit its own companies: As the 
Economist noted in 2011, the Chinese government "has been widely accused of twisting rules in favour of its state-owned or, sometimes, private-sector favourites." 2 The government may also have a greater ability to intervene because of its direct role in the supply chain. We document that this SOE-effect operates in part through the import choices of Chinese firms: there is a decline in Japanese imports by Chinese SOEs (relative to U.S. imports) following the Textbook Event (firm-level import statistics are unavailable following the Senkaku Event).

The insulating effect of high employment of Chinese workers may reflect beliefs that the Chinese government would be averse to harming companies that generate local jobs. The Chinese government has been particularly sensitive to this concern in its economic liberalizations and has emphasized employment creation as an objective for foreign investment specifically. ${ }^{3}$

We provide suggestive evidence on the role of consumer response in the two countries. For Japanese firms, we find no evidence that returns are affected by whether a company is focused on consumer (B2C) or business (B2B) customers, where the B2C versus B2B assignment is made using descriptions from the Japanese equivalent of 10-K filings, as would be the case if companies feared a long-term consumer backlash. ${ }^{4}$

\footnotetext{
2 "The Long Arm of the State," The Economist, July 23, 2011 (http://www.economist.com/node/18832034)

${ }^{3}$ See, for example, the State Council's 1995 "Provisions on Guiding Foreign Investment Direction," and the follow-up directives issued by the State Council in 2010, "Further Guidance from the State Council on improving our work on utilizing foreign direct investment."

${ }^{4}$ We assume that consumers rather than intermediate goods producers are more prone to have purchasing decisions influenced by non-pecuniary concerns. This assumption is implicit in the literature that examines the determinants and consequences of corporate social responsibility. See, for example, Besley and Ghatak (2007) for one prominent example.
} 
We find that sensitivity of market reaction to China sales share is also affected by the fraction of shares held by individual investors, and that the effect persists at least a month past each event's resolution. To the extent that individuals - as opposed to institutional investors - are more prone to trade based on emotion or sentiment, these findings suggest that the decline in China-focused firms was partly the result of selling by individual investors divesting their portfolios of (distasteful) China-focused companies. ${ }^{5}$

We find suggestive evidence that the decline in Chinese firms' value is driven by a contrasting set of factors - in neither episode are firms with high rates of Japanese exports more adversely affected in industries vulnerable to government intervention (drugs, agriculture, and foods). We find weak evidence that consumer-focused firms' returns suffer more than firms producing primarily for business customers (this difference is not statistically significant), providing suggesting that expectation of a Japanese consumer backlash could have played a greater role in explaining the decline of Japan-focused firms in China.

In our final section of analysis, we examine the longer-run consequences of the two episodes for firm performance. We do not observe complete reversion in share prices, as would be the case if the patterns we describe were only an indication of short-run investor overreaction. Returns on assets decline for Japanese firms with high China exposure (and

\footnotetext{
${ }^{5}$ See, for example, Lee, Shleifer, and Thaler (1991), De Long, Shleifer, Summers, and Waldmann (1990), Baker and Wurgler (2006), and Stambaugh, Yu and Yuan (2012) on individual investors and the role of sentiment; Daniel, Hirshleifer, and Subrahmanyam (1998), Daniel, Hirshleifer, and Teoh (2002), and Hirshleifer (2001) on individual investors and overreaction; and Bikhchandani, Hirshleifer, and Welch (1992) for a discussion of how small shocks can often lead to large shifts in behavior.
} 
for Chinese firms with high Japan exposure), consistent with investors' reactions correctly anticipating future profitability.

Overall, we conclude that companies' fortunes are very sensitive to relations between the two countries. We provide an array of evidence in support of the view that Chinese government intervention is an important contributor to Japanese companies' decline, along with tentative evidence that the decline in Chinese firms' values is driven more by consumer response. This does not imply that citizen sentiment is irrelevant for Japanese firms, but rather that it may find expression more through its impact on government policy than individual consumer choice. Overall, our results on the contrasting determinants of firm-level responses to the two events highlight the importance of considering the different channels through which nationalism and other interstate frictions impact economic activity. ${ }^{6}$

Our work contributes most directly to a recent literature relating hostilities among countries to cross-border economic activity. Contributions include studies on the impact of diplomatic frictions such as Gupta and Yu (2009), which examines whether bilateral political relations can explain investment and trade flows between the United States and other countries, the effects of military hostility (e.g., Glick and Taylor 2010; Martin, Mayer, and Thoenig 2008), the impact of cultural aversion and mistrust on trade and investment (Guiso et al. 2009; Michaels and Zhi, 2010), the effect of country-specific sentiment on security prices (Hwang 2011), the role of cultural value in mergers (Ahern,

\footnotetext{
${ }^{6}$ It is of course possible to speculate on why we observe these differences - the Chinese government might be seen as still playing a more dominant role in economic activity than in Japan - but given that we effectively only have two data points, we leave such questions about underlying economic systems for future research.
} 
Daminelli, and Fracassi 2012), the impact of patriotism on the home bias in asset allocation (Morse and Shive 2010) and the role of ethnic differences in exacerbating trade frictions (Aker, Klein, O'Connell, and Yang 2010). When compared to many of these studies, our event study provides a credible causal estimate of the firm-level impact of interstate frictions on valuations. Relatedly, since we employ firm-level data we are better able to identify the channels underlying such an effect. Equally important, given the slow-moving nature of interstate animosity, our setting provides a unique opportunity to assess the impact of changes in interstate frictions on firm value.

Our study also relates to work examining the impact of boycotts on firm value. These include several event studies, which find mixed results (see, for example, Epstein and Schnietz 2002 for the effect of consumer boycotts; Teoh, Welch, and Wazzan 1999 on the impact of South African boycott announcements). Also related is a pair of recent studies on the effect of consumer backlash on French wine purchases in the United States following France's protests against the Iraq War (Ashenfelter, Ciccarella, and Shatz 2007; Chavis and Leslie 2009). These papers provide a much coarser inference on the effects of consumer sentiment, which may account for the disagreement between them (e.g., calendar effects in wine sales may account for the impact on sales attributed to consumer boycott in one paper). By contrast, our detailed data on companies' foreign exposure facilitates a better identification of the impact of interstate frictions on firm value.

Finally, several very recent papers in political science have examined the 2005 protests we consider here, and also other smaller-scale shocks to Sino-Japanese relations. Davis and Meunier (2011) study the impact of increased Sino-Japanese (and U.S.-French) 
frictions on trade and investment flows, and in contrast to our findings here, report no effect. This non-result may stem from the relatively coarse, low-frequency nature of trade and FDI flows as measures of changed economic relations. Weiss (2008) also examines the 2005 protests, with a focus on political relations between the two countries, with less of a quantitative focus relative to our study. Finally, in work concurrent with our own, Govella and Newland (2011) also take an event study approach, looking at the effect of the 2005 protests on the value of Japanese companies. Our data allow for a more fine-grained analysis of equity market responses, owing to more detailed data on companies' foreign exposure. We further provide results based on industry variation that are critical to understanding the underlying mechanism - populist sentiment versus government intervention - behind the negative market response.

\section{Background and data}

\subsection{Sino-Japanese economic and political relations}

We provide a brief overview of the Textbook and Senkaku events, which took place against a historical background of generally tense relations between China and Japan. For the interested reader, in Appendix A, we provide a short description of the history of SinoJapanese relations and national sentiment in China and Japan in recent years.

Before describing the two events, it is worth noting that the two nations' relationship has for decades been an ambivalent one. There is a high degree of animosity; most notably, the two countries fought two wars - one at the end of the nineteenth century and a second in the first half of the twentieth century. Relations to this day are affected by 
the notorious Nanjing Massacre perpetrated by the Japanese military in 1937. At the same time, the two countries are highly dependent on one another economically - China is Japan's largest trading partner and Japan is China's second largest, after the United States.

It was against the backdrop of this tense - yet ambivalent - relationship that antiJapanese demonstrations in China were set off in the spring of 2005. The primary cause of the protests was Japanese government approval of "Atarashî Rekishi Kyôkasho," or the New History Textbook, written by the Japanese Society for History Textbook Reform, which Chinese critics claimed whitewashed Japanese war crimes committed during World War II. $^{7}$

Large-scale protests began on April 5 and lasted for several weeks, with the final protest occurring on April 27. We use a window of April 5 - 28 for our analyses. ${ }^{8}$ Right- $^{-}$ wing nationalist demonstrations against China were also seen in Japan during this period, but on a much smaller scale.

The second event we consider, the 2010 Senkaku Boat Collision incident, occurred on the morning of September 7, 2010 when a Chinese trawler collided with Japanese Coast Guard patrol boats in disputed waters near the natural gas-rich Senkaku (Diaoyu in Chinese) Islands. ${ }^{9}$ The collision and Japan's subsequent detention of the captain triggered a major diplomatic dispute between China and Japan, and inflamed nationalist sentiments in both nations. When China's repeated demands for the captain's release were refused and

\footnotetext{
${ }^{7}$ Anti-Japanese sentiment had already been building as a result of the G4 proposal that Japan be granted a permanent seat on the United Nations Security Council.

${ }^{8}$ The impact of China exposure on Japanese firms is even larger if we extend the window back to the earliest Security Council protests in March 2005.

${ }^{9}$ Japan controls the islands, but both China and Taiwan claim them.
} 
his detention extended for a further ten days, the Chinese government cancelled all ministerial-level meetings between the two countries. On September 24, Japan released the captain, citing in part the effect on Sino-Japanese relations. The Senkaku Event again brought about a series of demonstrations against Japan and Japanese products across China, beginning in Beijing on September 8, then spreading to many other cities. Protests continued through to the end of October, with the final demonstrations reported on October 28. We take September 7 - October 29 as our event window.

In contrast to the sharp reaction from the Chinese, Japan's government and media were reserved in their handling of the Senkaku Event. Facing decisive protest from China, the Japanese central government interceded to push the judicial branch to release the captain without prosecution. Likewise, the Japanese media underplayed Japanese protests against China. While protests took place, they were limited in number and scale - about 20 in total, with few generating crowds exceeding a thousand, from September 7 to October 29, 2010.

\subsection{Data}

For Japanese listed firms, we calculate their Chinese exposure using business segment data from annual filings with the Ministry of Finance (Yûka Shôken Hôkokusho), which is the $10-\mathrm{K}$ equivalent in Japan. There are three dimensions along which company accounts are disaggregated; (1) by types of business or products, (2) by locations of sales offices (including domestic regions), and (3) by overseas sales, if sales in foreign markets exceed 10 percent of consolidated total sales. For each segment, firms are required to report 
sales (to other segments as well as to external customers), operating expenses, profit or loss from operations, and assets. We utilize the overseas sales information to construct variables that indicate each firm's exposure to the Chinese economy. Firms differ in their geographical classifications for sales: some use broad regional categories (e.g., Japan, North America, Europe, Asia, and Other) whereas others provide some country-level disaggregation. In some cases, broad categorizations are supplemented by country sales in footnotes. We use both the explicit categorization of "China (or People's Republic of China)" and footnoted supplements to estimate the percentage of sales in China out of firm's total sales. We also compute the fraction of assets in China. These measures are used to identify firms with high exposure to China.

For the 2005 Textbook Event, we have 846 Japanese non-financial firms with information on sales and assets in China, and for the 2010 Senkaku Event, we have 920 non-financial firms in our sample. Other publicly listed firms were excluded because of non-disclosure of regional sales information, which could be either the result of a deliberate decision to avoid disclosing detailed segment data, or because the company had negligible foreign sales more broadly. Using this information, we construct our key dependent variable Fraction_China_Sales, the ratio of sales in China to total sales. Some firms may have Chinese plants that do not directly sell products in China. To capture this operating exposure, we also calculate Fraction_China_Assets, the ratio of total assets in China to total assets of the listed firm. For Japanese firms, we further calculate Fraction_Others_Sales as the ratio of sales in all foreign countries other than China to total sales,. 
For the 1,058 Chinese listed firms in our sample, we calculate Japanese exposure based on the ratio of exports to Japan to total sales, defined as Fraction_Japan_Exports, using a match between the listed firms in our sample and transaction-level trade data from China Customs, also employed by Ahn, Khandelwal, and Wei (2010). The trade data are publicly available only through 2005 ; hence, we use 2004 data to construct our Japan export measure for both events. We also calculate Fraction_Others_Exports as the ratio of exports to all foreign countries other than Japan to total sales, for the sample of Chinese firms.

To investigate the channels through which adverse shocks to Sino-Japanese relations affect stock returns, we generate proxies for government and consumer vulnerability. First, we calculate a proxy for the extent of Chinese government intervention based on the prevalence of state owned enterprises across industries. China's economic reforms have not been accompanied by the same degree of political liberalization (Calomiris, Fisman, and Wang 2010). State companies continue to play a significant role in achieving political ends (in addition to economic targets), as documented in a report by the U.S.-China Economic and Security Review Commission (2011) and also emphasized by Bräutigam (2011) and $\mathrm{Yu}$ (2011), among many others. We proxy for potential for government intervention using industry-level SOE intensity. Our reasoning is that the sectors where SOEs dominate economic activity are those where the government is most inclined and best positioned to intervene via, for example, direct competition, trade 
policies, and purchasing embargoes by SOEs against Japanese goods. ${ }^{10}$ We use the 2004 and 2008 Economic Census of China conducted by the National Bureau of Statistics of China (NBSC), which include firm-level information on the sales and primary ownership of the universe of firms operating in China. ${ }^{11}$ Using the 2-digit industry classifications of the NBSC we generate the industry-level variable SOE_Intensity, the ratio of total sales by state-controlled firms to total sales of all domestic Chinese firms in each industry. We match the NBSC 2-digit industry classifications to their Japanese equivalent (Nikkei Industry Code, Medium Level ${ }^{12}$ ) to match this measure to our sample of Japanese listed firms.

The number of employees for Japanese businesses in China is obtained from a database maintained by Tokyo Keizai. Each year, the company surveys Japanese firms to obtain information on their overseas joint ventures, foreign branches, and representative offices. The information in their database includes location, number of employees, amount invested, equity shares of partners (in case of joint ventures), and so forth. The data we use are for employment in joint ventures, branches, and representative offices in China for March 2005 and March 2010. These employment figures distinguish between expatriate and Chinese workers. We define Fraction_China_Empl as the number of Chinese employees in China for each Japanese firm as a fraction of total firm employment worldwide, which comes from Yûka Shôken Hôkokusho.

\footnotetext{
${ }^{10}$ In a similar spirit, Bertrand, Kramarz, Schoar, and Thesmar (2008) also illustrate the impact of politics on firms' hiring decisions in France.

${ }^{11}$ Ideally we would use the 2009 data for the 2010 event study. Unfortunately, there was no industry census in China in 2009.

${ }^{12}$ Nikkei Industry Code closely follows the Japan Standard Industry Classification.
} 
We also construct a proxy for Japanese government involvement in business with China. Drugs_and_Food is an indicator variable for Chinese firms whose primary operating industry is food, agricultural products, or medicine. The Japanese government itself is less deeply involved in the business operations of Japanese firms than is the Chinese government in Chinese business, and thus has fewer levers to impact foreign firms. The selection of these three industries is a matter of subjective judgment, reflecting the following considerations: first, farmers in Japan have been influential constituents and the Japanese government has a history of protecting domestic agriculture (Honma 1993; OECD 2009); second, Chinese exporters have had numerous problems over the years with food and drug safety, resulting in recalls and import bans in Japan and elsewhere (see, for example, Qian 2011). Hence it would be relatively easy for the Japanese government to find a premise for restricting or even banning Chinese imports in these industries.

To examine the potential effects of consumer sentiment, we generate a companylevel proxy for consumer vulnerability (Consumer_Intensity) using business segment descriptions to classify companies as primarily business-to-business (B2B) or business-toconsumer (B2C).

For Japanese firms, we use information from Yûka Shôken Hôkokusho to classify firms as $\mathrm{B} 2 \mathrm{~B}$ or $\mathrm{B} 2 \mathrm{C}$ based on the segment that has the highest fraction of sales. This source provides business segment classifications that are similar to the most detailed level of the Japan Standard Industry Classification, making it relatively straightforward to identify a firm's consumer orientation. For example, Omron in 2005 lists five segments: “industrial automation," “electronics components," "social systems business," "healthcare 
business," and "others," with "industrial automation" as the top-selling segment. It is thus classified as B2B. Hitachi reports their best-selling segment as "power generation and industrial systems" while their "digital media and consumer goods" segment has sales of less than half of former. Thus Hitachi is also classified as B2B.

Where companies do not report segments clearly enough to make an assignment of B2B or B2C (135 firms), we consult company websites directly for more detailed descriptions of company activities. In the vast majority of cases, the assignment was clear. For example, Sony's largest selling segment in 2005 is "electronics," while other segments are listed as "games," "movies," "financial," and "others." Inspection of their website confirms that the majority of their products are for consumers, despite also manufacturing video cameras for professional broadcasting and filming (which are included in "electronics"). Thus Sony is classified as B2C. While this method admittedly has a subjective component, it allows for a more fine-grained - and accurate - assignment than other industry-level aggregates. (We also produced industry-level proxies for consumerintensity based on U.S. input-output tables that provide some indication of whether industries produce primarily intermediate or end-use products. But this fails to distinguish, for example, between home and business applications in the electronics industry.)

Consumer_Intensity for Chinese firms is constructed using descriptions from the Chinese equivalent of 10-K filings (Nianbao, or annual report). It is equal to 1 if the firm mainly produces products that are sold to consumers directly. We construct our consumerintensity variable in much the same manner as with Japanese firms, which was straightforward in the majority of cases (e.g., Shangdong Haihua, whose main products 
include "polyvinyl chloride, sodium nitrate, and nitrobenzene, etc." is classified as B2B). Some cases highlight the problematic nature of making industry-level classifications, which reinforces the benefits of the firm-level approach we take here. For example, included in the Utility category are both Guiguang Electricity and Datong Gas. Guiguang Electricity mainly generates electricity for utility suppliers (B2B) while Datong Gas directly provides gas to households (B2C).

In the 79 cases that were indeterminate based on product categories, Original Chinese company reports were examined to make a subjective determination. For example, Jiangsu Yangguang reports its main business segments as "wool fabric, wool yarn, textile, and apparel." Wool fabric is sold to firms as intermediary goods, while apparel is usually sold directly to consumers. A more detailed reading of its report indicated that its main line of business was high-quality wool fabric for apparel manufacturing firms, and it was thus coded as B2B.

We construct firm-year variables, Fraction_Indiv_Japan and Fraction_Indiv_China, which are the ratios of individual ownership to total outstanding shares. These variables serve as proxies for the vulnerability of share price to investor sentiment (see Lee, Shleifer, and Thaler 1991; De Long, Shleifer, Summers, and Waldmann 1990; Baker and Wurgler 2006; and Stambaugh, Yu, and Yuan 2012 for examples). For Japanese firms, information on individual versus institutional ownership is taken from Yûka Shôken Hôkokusho, and for Chinese firms we obtain these data from GTA, a Shenzhenbased data vendor in China, now partially available through the Wharton Research Data Service. 
We obtain standard firm-level financial variables, including total leverage, total assets and Tobin's Q as controls for Japanese firms, as well as stock price data from the Nikkei database. Chinese stock prices and financial variables (total assets, total leverage, and Tobin's Q) are obtained from GTA. A standard Fama-French three factor model (Fama and French 1993) is used to calculate the abnormal event returns for both samples. ${ }^{13}$ For predicting normal returns, we use the window of [-150, -30] (in trading days), where 0 is the event date, to estimate the parameters for the Fama-French three factor model.

We calculate the cumulative abnormal returns (henceforth CARs) over the period of April 5 - April 28 inclusive for the 2005 Textbook Event, and September 7 - October 29 for the 2010 Senkaku Event. For the 2005 Textbook Event, we also calculate the CARs over the period of March 26 - April 28 and find similar results.

Finally, we will also present analyses on the imports of Chinese firms in the wake of the Textbook event. The data we collected for this purpose are distinct from those utilized in the rest of our analyses, and involve firm-product level import data from Japan and U.S. for all Chinese firms. The data are taken from China Customs (with firms' names anonymous), and are available for the years 2004 to 2006 (hence we are unable to examine the Senkaku Event). The dataset provides information on the declared value of imports, its 8-digit Harmonized System (HS) industry classification, the date of importation, and the

\footnotetext{
${ }^{13}$ Fama-French (1993)-type effects are first documented in Japan by Chan, Hamao, and Lakonishok (1991), and three factors for Japan are computed as Kubota and Takehara (2007). For China, the Fama-French three factor model is examined by Wang and $\mathrm{Xu}$ (2005), and the factors for China are computed and provided by RESSET, a Beijing-based data vendor. We also use a simple market model (MacKinlay 1997) to calculate the abnormal event returns and obtain near-identical results.
} 
country of origin. ${ }^{14}$ Additionally, the data include whether the importer is a state-owned enterprise (SOE). We use these data to construct a measure of the intensity of imports from Japan for SOEs versus private firms, benchmarked against imports from the United States as a control. Specifically, we define State as an indicator variable denoting whether an importer is an SOE, and at the HS-State-month level define JPN_Import_Rate as the ratio of Japanese imports to the sum of Japanese and U.S. imports.

\subsection{Summary Statistics}

Table 1, Panels A and B present the summary statistics for Japanese and Chinese listed firms, respectively. As indicated in Panel A, the market value of our sample of Japanese firms fell by 5.8 percent (Fama-French three factor model adjusted) on average during the 2005 Textbook Event, with a standard deviation of 5.8 percent; the Wilcoxon signed-rank test rejects the null hypothesis that the cumulative abnormal return is zero at the 1 percent level. Chinese listed firms dropped by about 3.8 percent during the same period, with a standard deviation of 12.2 percent; the Wilcoxon signed-rank test rejects the null hypothesis at the 1 percent level. During the 2010 Senkaku Event, Japanese firms experienced a cumulative abnormal return of -3.7 percent with a standard deviation of 11.2 percent (the Wilcoxon signed-rank test rejects the null hypothesis at the 1 percent level), while Chinese firms increased by 1.5 percent with a standard deviation of 13.7 percent. $^{15}$

\footnotetext{
${ }^{14}$ The HS classification is the standard system for international trade. 8-digit categories involve a very high degree of disaggregation, for example, "Diesel powered trucks with a GVW exceeding twenty tons" and "Tobacco, partly or wholly stemmed (stripped), threshed or similarly processed, from cigar leaf."

${ }^{15}$ The discrepancy with the market returns reported in the introduction stems from two differences. First, the Japanese firms in our sample are only those that report country-specific sales data; second, we employ a
} 
Among Japanese listed firms, about 18 percent of our sample firms mainly sell products to consumers, while for Chinese listed firms, the figure is 38.8 percent.

In Tables 2A and 2B, we present industry-level characteristics for Japanese and Chinese firms respectively. Consumer-intensity measures reveal few surprises - in the Japan sample, Petroleum has a consumer-intensity of zero and for Machinery it is 0.027 , while Foods and Drugs have consumer intensities of 0.75 and 0.57 respectively. We note that the difference in consumer-intensity of Japanese versus Chinese firms is accounted for in large part by a differential distribution across industries. For example, in China 4.8 percent of publicly traded firms are in the "Retail Trade" industry, while 1.4 percent of Japanese companies are in this consumer-focused segment. By contrast, 8.3 percent of Japanese firms are in "Wholesale Trade" - a B2B segment - as compared with 1.1 percent in China. Some industries do differ in their consumer-intensity between the two samples. Most striking is "Real Estate Development", where nearly all (95.2 percent) Chinese firms are consumer-focused as compared to 0 percent in the Japanese sample. This is a reflection of the different roles of real estate firms in each country. In China they market apartments and homes directly to consumers, while listed Japanese real estate firms are more focused on commercial properties. Table $2 \mathrm{~A}$ also shows an industry-by-industry breakdown of SOE_Intensity for 2004 (these figures are very similar for 2008). Recall that while this is a variable we use in our analysis of Japanese firms, the industry-level figures reflect SOEintensity for Chinese industries. Infrastructure industries like warehousing, sea and railroad transportation are characterized by very high levels of government ownership.

market-adjustment in returns for the data reported in Table 1, while the figures in the introduction are based on raw market index returns. 


\section{Empirical Framework and Results}

We combine an event study on the market returns of Chinese and Japanese firms with a regression framework for examining whether returns are correlated with exposure to Sino-Japanese trade. Specifically, we use the cumulative abnormal event returns of publicly traded firms in Japan and China over the Textbook and Senkaku Event windows, then correlate these returns with exposure to Sino-Japanese relations, as proxied by sales in (or exports to) the partner country. Effectively, we employ those with zero partner-country sales as a control group to benchmark the firm-level impact of companies with positive sales. We present our results in a regression framework, where we control for firm size, performance, industry, and other relevant attributes. Thus, for example, for Japanese firms during the Textbook Event, we perform the following analysis, which looks at the correlation between China sales exposure and returns over the event window of April 5 28, 2005:

$$
\text { CAR_Textbook }{ }_{i}=\alpha+\beta_{1} \text { Fraction_China_Sales }_{i}+\boldsymbol{\beta}_{2} \text { Controls }_{i}+\varepsilon_{i}
$$

for firm $i$ where CAR_Textbook is cumulative abnormal returns over the event window

[April 5, April 28], controls include the logarithm of total assets, Tobin's Q, leverage in 2004, and industry dummy variables for Nikkei Industry Code (U.S. SIC 2-digit equivalent).

\subsection{Main results}

Table 3, column (1) presents the basic specification with $\log$ (TotalAssets) as the only control. The coefficient on Fraction_China_Sales is negative and significant at the 1 
percent level. The coefficient of -7.49 implies that a one standard deviation increase in the China sales ratio - about 0.1 in the sample - corresponds to a change in cumulative abnormal returns during the incident of -0.749 percent. In columns (2) and (3) we observe that the relationship between China exposure and returns during the Textbook Event is insensitive to the addition of controls, including industry dummies. It is noteworthy, in particular, that the coefficient on Fraction_Others_Sales is positive though not significant, implying that vulnerability to China trade is not simply proxying for international exposure more broadly. ${ }^{16}$ Using assets as a measure of China exposure in column (4) implies essentially the same level of impact (while the coefficient on our asset-based measure of China exposure is marginally smaller, the asset-based measure has a higher standard deviation).

Columns (5) - (8) repeat the analysis from specification (1) using CAR_Senkaku (cumulative abnormal returns during September 7 - October 29, 2010) as the outcome variable, and covariates calculated using firm-level data from 2009. The coefficient on Fraction_China_Sales is three times greater in this set of regressions, reflecting in part several extreme values despite winsorizing. ${ }^{17}$ Finally, we pool the two events using Fraction_China_Sales and Fraction_China_Assets as measures of China exposure in columns (9) and (10) respectively, allowing for the effect to vary across the two events through an interaction term, and clustering standard errors at the firm-level. In this, as with all other specifications that pool data from both years, we include Industry $\times$ Year fixed

\footnotetext{
${ }^{16}$ In unreported results, we also included the fraction of sales to the United States as a control; its coefficient was not significant and it similarly had no effect on our estimates of the coefficients of interests

${ }^{17}$ Without winsorizing, the effect is twice as large.
} 
effects. The results reflect the patterns observed in the earlier columns - a strong negative effect of China exposure on returns, with a much larger effect from the 2010 Senkaku Event.

In Table 4, we present analogous results for the effect of the two events on Chinese firms, using Fraction_Japan_Exports as our measure of exposure of Chinese companies to the Japanese economy. It is worth noting that Chinese firms are much less exposed to the Japanese economy than Japanese firms are to China's - the $75^{\text {th }}$ percentile of Fraction_Japan_Exports is zero, as compared to 0.10 for Fraction_China_Sales. That said, the correlation between export exposure to Japan and returns during the textbook incident as indicated by the results in Table 4 column (1) - is negative and significant at the 5 percent level. The coefficient, -8.745 , is of a similar size as we obtained for our analysis of Japanese firms. Adding controls increases the implied effect of Japan exposure on abnormal returns (Columns (2) and (3)), implying a somewhat larger sensitivity for Chinese firms (relative to Japanese ones) for a given percentage point increase in exposure to SinoJapanese trade. We note as well that exports to other countries are positively correlated with returns, once again highlighting that our main findings are unlikely to be the result of international exposure more broadly.

The relationship between Fraction_Japan_Exports and returns is of a similar magnitude for the 2010 Senkaku Event (Columns (4) - (6)). In column (7) we pool the two events, allowing Japan exposure to vary by event through an interaction term, clustering standard errors at the firm-level and including Industry $\times$ Year fixed effects. The results 
reflect the patterns reported in earlier columns, with a significant effect of Fraction_Japan_Exports, and a similar impact for each event.

In interpreting the results in Table 4, we note that the effect derives entirely from the minority of firms with non-zero exports. In column (8) we limit the sample only to observations where Fraction_Japan_Exports $>0$. The coefficient on Fraction_Japan_Exports is somewhat larger than in the full sample case and significant at the 10 percent level. (In results not shown, we find that an indicator variable for non-zero exports to Japan is actually positive, though the coefficient does not approach significance.)

Our methodology ascribes the negative relationship between corporate exposure to Japan/China and cumulative abnormal returns over the event windows to the effects of Sino-Japanese frictions. We would not, therefore, expect a significant pre-event relationship, nor would we expect any trend following each window. To examine graphically the pre- and post-event patterns in the data, we present in Figures $1 \mathrm{a}$ and $1 \mathrm{~b}$ the coefficient on Fraction_China_Sales from Equation (1), utilizing event windows that begin a week prior to the date we have set as the start of each event, and continuing to two months following each event. That is, each point represents a regression coefficient where the outcome variable is cumulative abnormal returns over the window [-7, date]; we include a $[0.05,0.95]$ confidence interval around the coefficient estimates. We do observe a preevent negative return for the Textbook Event in Figure 1a, reflecting that tensions that were already on the rise as a result of the announced proposal that Japan be given a permanent seat at U.N. Security Council. There is no such pattern for the Senkaku Event. In both cases, there is a steady decline in the Fraction_China_Sales coefficient over the event 
window. For the Textbook Event, the decline continues beyond the event period, while we see no such pattern for the Senkaku Event.

Turning to Chinese firms, we repeat the graphing exercise in Figures 1c and 1d, showing the coefficients on Fraction_Japan_Exports in regressions on cumulative abnormal returns. As in Figure 1a, we observe some evidence of pre-event declines prior to the Textbook Event for Chinese firms. We also, in this instance, observe complete reversion following the end of the event window. We observe neither pre-event decline nor reversion for the 2010 Senkaku Event.

Overall, the graphical representations of our findings over longer windows suggest that we would generate larger estimates of the effect of China-Japan exposure on returns if we extended our event window to incorporate the U.N. Security Council announcement that was also the source of frictions between the two countries. As a separate validation exercise, to alleviate concerns that vulnerability to Sino-Japanese relations is simply proxying for a broader sensitivity to market-wide shocks we provide a placebo test to formally reject the possibility that the effect we observe in the data is purely due to a China (Japan) effect for Japanese (Chinese) firms. That is, we assess the possibility that whenever there is a negative economic shock to China, Japanese firms suffer (and vice versa), whether or not the shock impacts sentiment between the two countries. We find no evidence of a link between exposure to Sino-Japanese relations and returns on September 11, 2001 or returns during the earthquakes that struck Niigata, Japan in 2007 and Sichuan, China in 2008. 


\subsection{Channels of impact}

We now turn to probe the channels that account for the sharp negative reaction to deteriorations in Sino-Japanese relations. The two main mechanisms through which interstate frictions may affect firm value are government intervention and consumer backlash. To the extent that government intervention is of primary concern, we may distinguish between differing governmental motives, in particular the protection of local jobs versus vulnerability to hold-up. While our data do not allow us to provide dispositive proof on the underlying mechanisms, the results in this section provide suggestive evidence on the different channels through which firms were adversely affected in the two countries.

We focus first on Japanese firms in Table 5. We include interactions of Fraction_China_Sales with Consumer_Intensity, a firm-level indicator variable denoting whether the company's main business segment focuses mainly on consumers, and SOE_Intensity, an industry-level measure of the presence of government-owned firms in China. We see this latter measure as an indication of the extent to which the Chinese government may be motivated - and able - to impact the profits of Japanese companies selling in China via competition, product embargoes, and trade policies. Finally, we include Fraction_China_Empl to capture the potential effects of a firm employing a high rate of Chinese workers. We present all results for both events pooled together, and as before include Industry $\times$ Year fixed effects as well as Fraction_China_Sales $\times$ Year2010 as a control. $^{18}$

\footnotetext{
${ }^{18}$ Results disaggregated by year are available from the authors. All coefficients are directionally the same as those reported here.
} 
In columns (1) and (2), we include the interaction terms SOE_Intensity and Consumer_Intensity separately. The coefficient on Fraction_China_Sales $\times$ SOE_Intensity is negative and significant at the 1 percent level. To provide a sense of its magnitude, consider two industries where a reasonably high fraction of Japanese companies have nonzero sales in China, but very different levels of SOE-intensity: Drugs (SOE_Intensity $=$ $0.06)$ and Construction $\left(S O E_{-}\right.$Intensity $\left.=0.26\right)$. The estimates imply that a one standard deviation increase in Fraction_China_Sales reduces returns by about 0.66 percent for Drug companies $(0.1 \times 0.06 \times 109.8)$, versus 2.85 percent for Construction $(0.1 \times 0.26 \times 109.8)$. The coefficient on Fraction_China_Sales $\times$ Consumer_Intensity is positive, though it is very small in magnitude, and quite precisely estimated as close to zero - we can reject at a 95 percent confidence level that the coefficient is less than 12.3 (i.e., $2.87+7.75 \times 1.96$ ). In column (3), we include Fraction_China_Empl as a covariate. Its coefficient is positive and significant at the 10 percent level (we obtain similar results if we further control for Fraction_China_Assets). In the final column we include all interaction terms simultaneously. Note that the sample size decreases by half owing to the limited availability of Chinese employee information. As a result, the SOE_Intensity interaction term is no longer significant $(p$-value $=0.12) ;$ Fraction_China_Empl is also no longer significant at conventional levels $(p$-value $=0.12)$.

We next examine one channel through which Japanese firms - particularly those with the Chinese state as a customer - may have been adversely affected following the Textbook Event. 
We use the following specification to examine whether, following the 2005 Textbook Event, Chinese SOEs decreased their imports of Japanese relative to U.S. goods, relative to private firms:

$$
\begin{array}{r}
J P N_{-} \text {Import_Rate }_{h s m}=\alpha+\beta_{1} \text { After }_{m}+\beta_{2} \text { State }_{s}+\beta_{3} \text { After }_{m} \times \text { State }_{s} \\
+\beta_{4} \text { Month }_{m} \times \text { State }_{s}+H_{h}+M_{m}+\varepsilon_{h s m}
\end{array}
$$

The data employed in these analyses are entirely distinct from those employed elsewhere in the paper, as noted in the Data section. All analyses are done at the HS8-ownership typemonth level, where $J P N_{-}$Import_Rate is fraction of imports by firms in 8-digit HS industry $h$ of ownership type $s$ in month $m$ that are from Japan (relative to imports from Japan and the United States combined); State is an indicator variable for state ownership; and After indicates that month $m$ comes after the Textbook event (i.e., May, 2005 or later). All specifications include 8-digit HS and month fixed effects, as well as firm-type time trends to account for differential import rates of SOE versus private firms over time (our point estimates are much larger if we do not include these terms). These results are reported in Table 6. The coefficient on After $_{m} \times$ State $_{s}$ in column (1) is negative, though not statistically significant at conventional levels $(p$-value $=0.126)$. Its magnitude of -0.007 is relatively modest, implying a 0.7 percentage point decline in imports from Japan relative to the United States (as compared to the sample mean of 0.65 for JPN_Import_Rate overall). In Column (2) we limit the sample just to those industries with "thick" trade such that in each month-industry in our sample, there is non-zero importation for both private and SOE 
importers from either Japan or the United States. The point estimate increases slightly, and is significant at the 10 percent level. In Columns (3) and (4) we repeat our analyses including State-by-HS fixed effects to allow for a differential level of imports by industry for state versus private firms. The magnitudes of our coefficients estimates are virtually unchanged, though they are estimated with slightly greater precision.

We now turn to examine the channels through which Chinese firms may have been adversely affected by the two events, using specifications that parallel those presented in in Table 5. (Chinese firms engage in virtually no offshoring to Japan, so we do not consider the effects of labor- versus capital-intensity of production. ${ }^{19}$ ) The broad patterns, shown in Table 7, contrast with those we observe for Japanese companies, with negative and statistically significant coefficients on Fraction_Japan_Exports in all specifications. The interaction term Fraction_Japan_Exports $\times$ Drugs_and_Food does not approach significance, and its sign is positive. The lack of any measurable effect may result from the modest involvement, relatively speaking, of the Japanese government in commerce; alternatively, it may simply be because of the coarseness of our proxy for vulnerability to government intervention. ${ }^{20}$ In column (2) the sign on Fraction_Japan_Exports $\times$ Consumer_Intensity is negative, though not statistically significant ( $\mathrm{p}$-value $=0.20$ ); we observe similar patterns when both interaction terms are included in column (3).

To summarize the results thus far, both Japanese and Chinese firms with substantial Sino-Japanese economic ties suffer relative declines in value as a result of negative shocks

\footnotetext{
${ }^{19}$ In practice, we find that interactions of Fraction_Japan_Exports with the logarithm of labor and assets are very small in magnitude and significance.

${ }^{20} \mathrm{We}$ also used a proxy for government intervention based on tariff and non-tariff trade barriers from UNCTAD's TRAIN database, which similarly yielded no significant results.
} 
to relations between the two countries. This effect is more pronounced for Japanese firms operating in industries where the Chinese economy is dominated by state-owned enterprises; further, the effect is less pronounced for labor-intensive firms. By contrast, the effect for Chinese companies is more pronounced for consumer-oriented firms (though this result is not statistically significant).

Overall, our evidence indicates that Chinese government intervention was likely an important mechanism through which Japanese companies were affected; we provide weaker, suggestive evidence that consumer response played a larger role for Chinese companies. These patterns highlight the importance of considering differing channels through which cultural and political frictions impact economic activity, based on the economic institutions in affected countries. $^{21}$

\subsection{The role of investor sentiment}

We have assumed thus far that investors' responses reflect beliefs about firms' future profitability. But our main findings could also be the result of investor sentiment in the form of either overreaction (Daniel, Hirshleifer, and Subrahmanyam 1998; Daniel, Hirshleifer, and Teoh 2002; Hirshleifer 2001) or shifts in preferences over asset allocation (Bikhchandani, Hirshleifer, and Welch 1992). We follow the behavioral finance literature (Lee, Shleifer, and Thaler 1991; De Long, Shleifer, Summers, and Waldmann 1990; Baker and Wurgler 2006; Stambaugh, Yu, and Yuan 2012) in using the prevalence of individual

\footnotetext{
${ }^{21}$ One further concern is that our findings may reflect anticipation of embargos in industries engaged in military-related production. However, we discovered - in hindsight unsurprising - that no Japanese firms with sales in China are in this category to begin with, and similarly no Chinese exporter to Japan is engaged in military-related production.
} 
investors to proxy for the role of sentiment under the premise that they are more prone to sentiment-based trading than institutional investors. ${ }^{22}$ We thus augment Equation (1) with the term Fraction_Indiv_Japan $\times$ Fraction_China_Sales to capture whether sensitivity of returns to China exposure is higher for firms with a greater portion of individual rather than institutional investors. The results, in column (1) of Table 8, indicate that increasing ownership through individuals by one percentage point increases the coefficient on Fraction_China_Sales by 1.62 . As one may observe in our summary statistics, the mean of Fraction_Indiv_Japan is only about 0.01 for Japanese firms - and indeed the $90^{\text {th }}$ percentile is only 0.2 - so in general ownership is dominated by institutions. We therefore also consider whether our results are robust to considering splits of the sample based on whether a firm has an appreciable portion of individual investors that could plausibly move asset prices. We consider thresholds of 1, 5, 10, and 20 percent in columns (2) - (5) which replace Fraction_Indiv_Japan with indicator variables denoting that a firm has individual ownership greater than $p$ percent, I(Fraction_Indiv_Japan $\geq p)$. The coefficient is very stable at around -35 , indicating a much higher sensitivity of returns to China exposure for firms with a high proportion of individual investors. This effect is independent of the patterns related to government intervention and consumer preferences that we document in Table 5 - when Fraction_Indiv_Japan $\times$ Fraction_China_Sales is included as a control in those specifications, our earlier results are virtually unchanged.

\footnotetext{
${ }^{22}$ Sentiment is in general defined as the difference between the beliefs of sentiment-driven traders and correct objective beliefs conditional on available information (e.g., De Long, Shleifer, Summers, and Waldmann, 1990). Individual investors are typically viewed as natural candidates for sentiment-driven investors. Kumar and Lee (2006) analyze 1.85 million individual-investor transactions and interpret systematic factors in the investors' trades as being consistent with the influence of sentiment.
} 
We report analogous results for Chinese firms in Appendix Table 1. In contrast to Japanese firms, individual share ownership is ubiquitous in China, so Fraction_Indiv_China has a mean of 0.80 . We do not find any evidence of greater sensitivity of returns to Japanese exposure for firms with high individual ownership. These findings echo our earlier results emphasizing the role of individuals in mediating the effects of Sino-Japanese tensions in the case of Japan - in our earlier results we documented tentative evidence on the role of consumers, while our findings on sentiment emphasize the role of individual investors.

As already noted, the sentiment of individual investors could reflect an increased aversion to holding stocks engaged in Chinese commerce, or an overreaction to news of frictions with China. In the next section, we take up the concerns of whether our results more generally reflect investor overreaction to the fraying of Sino-Japanese relations.

\section{Longer-run analysis}

\subsection{Price reversion}

If investors overreact in the short run, we would expect that stock prices would gradually revert for affected firms following our event windows. The graphs in Figure 1 indicate that, overall, this is unlikely to be the case. In this section, we examine this possibility more formally.

We perform two tests to investigate possible overreaction. First, we calculate cumulative abnormal returns over the window of [end date, end date +60 ] where end date is the last date we included in our CARs calculations above. The overreaction hypothesis 
would predict that the Fraction_China_Sales (and Fraction_Japan_Exports) should positively affect these post-event CARs. We do not observe any such pattern in the data (all results for extended windows available on request). Second, we extend our event window to incorporate an extra 30 or 60 trading days after the day we identified as the end date. The overreaction hypothesis would predict that the Fraction_China_Sales (and Fraction_Japan_Exports) would have no effect on these extended CARs; however, we find that the negative effect still holds.

We also augment these analyses to include Fraction_Indiv_Japan $\times$ Fraction_China_Sales (or Fraction_Indiv_China $\times$ Fraction_Japan_Exports). This helps to adjudicate between sentiment-based explanations that involve individual investor overreaction versus those involving an increased aversion to ownership of companies with ties to China (or Japan). We find that extending our event window by 30 days generates very similar results to those reported in Table 7; if we extend the event window by 60 days, the interaction term Fraction_Indiv_Japan $\times$ Fraction_China_Sales falls by about half and is no longer significant, which is suggestive of the investor sentiment effect. This may result in part from foreign or institutional investors - that are less prone to sentiment purchasing undervalued equities. The fact that we do not, more generally, observe a complete reversion (note that the effects of sentiment are almost by definition temporary) over longer windows indicates that there is a long-run real effect on firm value.

Overall, we thus find at most limited evidence of a role for overreaction in explaining the negative impact of Sino-Japanese relations on returns. 


\subsection{Long-term effect on profits}

We examine the long-term effect of the 2005 shocks on Japanese and Chinese firms' profits by constructing a panel for 2002 - 2008 (i.e., three years before and after the 2005 shock). We consider specifications of the form:

$$
\begin{aligned}
\text {ROA }_{i y+1}= & \alpha+\beta_{1} \text { Fraction_China_Sales }_{i y} \\
& +\beta_{2} \text { Fraction_China_Sales }_{i y} \times I(\text { year } \geq 2005) \\
& +\boldsymbol{\beta}_{3} \text { Controls }_{i y}+\delta_{i}+\eta_{y}+\varepsilon_{i y}
\end{aligned}
$$

where ROA is defined as (net income)/(total assets), I(year $\geq 2005)$ is an indicator variable that is equal to 1 for years after 2005, and $\delta_{i}$ and $\eta_{y}$ are firm and year fixed effect. That is, we investigate whether there is an increase in the correlation between accounting profits and China exposure in the years following the Textbook Event. In the first pair of columns

in Table 9A, we show the results for Japanese firms. Returns on assets decline significantly following the Textbook Event, a result that persists when we allow for the interaction term $\log ($ Assets $) \times \mathrm{I}($ year $\geq 2005)$, to account for the possibility that the size-profit relationship is changing over time. In Table 9B, we present the results for Chinese firms, including Fraction_Japan_Exports and its interactions. We similarly observe lower profitability for Japan-exposed firms in the years following the Textbook Event, though the effects are not statistically significant ( $p$-value $=0.20$ in both specifications in Table 9B). We should note that this test provides complementary evidence to our event study; such a test cannot 
cleanly identify the effect of interstate frictions on firm value given the many shocks that took place during this period, which may also affect firms' profits.

Overall, the results in this section indicate that investors' beliefs that the profits of firms exposed to China-Japan commerce would be adversely affected by increased interstate frictions.

\section{Conclusion}

In this paper we study the impact of interstate frictions on economic exchange, by examining the impact of two major negative shocks to Sino-Japanese relations. As far as we know, this is the first paper to perform an in-depth econometric analysis of the effects of a discrete increase in Sino-Japanese frictions on economic relations, and also the first to attempt to examine the channels through which firms are affected.

We observe a large and adverse market response to negative shocks to SinoJapanese relations. This implies that economic exchange can be affected in discrete and sudden ways by increased animosity between countries. We also present evidence that a primary mechanism underlying this adverse reaction was likely government intervention in the case of Japanese firms vulnerable to trade with China. We present more tentative evidence that consumer response was a mediating factor for Chinese firms that export to Japan. (We find complementary results on the role of individual investors in affecting firm

value in Japan.) This result is consistent with the very different institutions governing the two countries - despite decades of economic liberalization, China's government remains deeply involved in the economy. This highlights the importance of considering the nature 
of economic institutions in understanding how economic actors will be affected by shifting relations between countries.

In concluding, we note that our paper plausibly provides a lower bound estimate of the impact of interstate frictions on firm value, since we only look at publicly traded firms. Unlisted firms, which are the majority in both countries, would likely be affected by the events we consider here. So while we cannot incorporate such an analysis due to data limitations, the impact on unlisted firms is important for a full accounting of the macro implications of interstate frictions.

While we focus in this paper on China and Japan, our approach may clearly be generalized to a broader set of country pairs to develop more deeply our understanding of how cross-country relations affect economic relationships. This would also give us a much broader set of institutional circumstances to study how economic, political, and social institutions mediate the effects of cultural animosity. We leave this for future work. 


\section{References}

Ahern, Kenneth, Daniele Daminelli, and Cesare Fracassi, 2012, "Lost in Translation? The Effect of Cultural Values on Mergers around the World," Journal of Financial Economics (forthcoming).

Ahn, JaeBin, Amit Kumar Khandelwal, and Shang-Jin Wei, 2011, "The Role of Intermediaries in Facilitating Trade," Journal of International Economics 84 (1): 73 - 85.

Aker, Jenny C., Michael W. Klein, Stephen A. O'Connell, and Munzhe Yang, 2010, “Are Borders Barriers? The Impact of International and Internal Ethnic Borders on Agricultural Markets in West Africa." Working Paper, Center for Global Development.

Ashenfelter, Orly, Stephen Ciccarella, and Howard J. Shatz, 2007, "French Wine and the U.S. Boycott of 2003: Does Politics Really Affect Commerce?" Journal of Wine Economics 2 (1): 55 - 74 .

Baker, Malcolm and Jeffrey Wurgler, 2006, "Investor Sentiment and the Cross-Section of Stock Returns," Journal of Finance 61 (4): 1645 - 1680.

Becker, Gary S., 1957, The Economics of Discrimination, 1st ed. Chicago: University of Chicago Press.

Bertrand, Marianne, Francis Kramarz, Antoinette Schoar, and David Thesmar, 2008, "Politically Connected CEOs and Corporate Outcomes: Evidence from France," Working Paper, Sloan School of Management, Massachusetts Institute of Technology.

Besley, Timothy, and Maitreesh Ghatak, 2007, "Retailing Public Goods: The Economics of Corporate Social Responsibility," Journal of Public Economics 91 (9): 1645 - 1663.

Bikhchandani Sushil, David Hirshleifer, and Ivo Welch, 1992, "A Theory of Fads, Fashion, Custom, and Cultural Change as Informational Cascades," Journal of Political Economy 100 (5): $992-1026$.

Bräutigam, Deborah, 2011, "Aid 'With Chinese Characteristics': Chinese Foreign Aid and Development Finance Meet the OECD-DAC Aid Regime," Journal of International Development 23 (5): $752-764$.

Calomiris, Charles, Raymond Fisman, and Yongxiang Wang, 2010, "Profiting from Government Stakes in a Command Economy: Evidence from Chinese Asset Sales," Journal of Financial Economics 96 (3): 399 - 412. 
Chan, Louis K.C., Yasushi Hamao, and Josef Lakonishok, "Fundamentals and Stock Returns in Japan," Journal of Finance 46 (5): 1739 - 1764.

Chavis, Larry, and Phillip Leslie, 2009, "Consumer Boycotts: The Impact of the Iraq War on French Wine Sales in the U.S.” Quantitative Marketing and Economics 7 (1): 37 - 67.

Daniel Kent, David Hirshleifer, and Avanidhar Subrahmanyam, 1998, "Investor Psychology and Security Market Under- and Over- Reactions", Journal of Finance 53 (6): 1839-85.

Daniel Kent, David Hirshleifer, and Siew Hong Teoh, 2002, "Investor Psychology in Capital Markets: Evidence and Policy Implications," Journal of Monetary Economics 49 (1): 139-209.

Davis, Christina L., and Sophie Meunier, 2011, "Business as Usual? Economic Responses to Political Tensions," American Journal of Political Science 55 (3): 628 - 646.

De Long, J. Bradford, Andrei Shleifer, Lawrence H. Summers, and Robert J. Waldmann, 1990, "Noise Trader Risk in Financial Markets" Journal of Political Economy 98 (4): 703738.

Epstein, Marc J., and Laren E. Schnietz, "Measuring the Cost of Environmental and Labor Protests to Globalization: An Event Study of the Failed 1999 Seattle WTO Talks," The International Trade Journal 16 (2): 129 - 160.

Fama, Eugene F., and Kenneth R. French, 1993, "Common Risk Factors in the Returns on Stocks and Bonds," Journal of Financial Economics 33 (1): 3 - 56.

Glick, Reuven, and Alan Taylor, 2010, "Collateral Damage: Trade Disruption and the Economic Impact of War," The Review of Economics and Statistics 92 (1): 102 - 127.

Govella, Kristi, and Sara Newland, 2011, "Hot Economics, Cold Politics? Re-examining Economic Linkage and Political Tensions in Sino-Japanese Relations," Working Paper, University of California, Berkeley.

Guiso, Luigi, Paola Sapienza, and Luigi Zingales, 2009, "Cultural Biases in Economic Exchange?” The Quarterly Journal of Economics 124 (3): 1095 - 1131.

Gupta, Nardini, and Xiaoyun Yu, 2009, “Does Money Follow the Flag?” Working Paper, Kelley School of Business, Indiana University. 
Hegre, Håvard, John Onea, and Bruce M. Russett, 2010, “Trade Does Promote Peace: New Simultaneous Estimates of the Reciprocal Effects of Trade and Conflict," Journal of Peace Research 47(6): $763-774$

Hirshleifer, David, 2001, "Investor Psychology and Asset Pricing," Journal of Finance 56 (4): $1533-1598$.

Honma, Masayoshi, 1993, “Japan's Agriculture Policy and Protection Growth,” in Ito, Takatoshi, and Anne O. Krueger (eds.), Trade and Protectionism, NBER-EASE 2:95-114, Chicago: University of Chicago Press.

Hwang, Byoung-Hyoun, 2011, "Country-Specific Sentiment and Security Prices," Journal of Financial Economics 100 (2): 382 - 401.

Kubota, Keiichi, and Hitochi Takehara, 2007, "Fama-French fakutâ moderu no yûkôsei no saikentô" [A Reexamination of the Effectiveness of the Fama-French Model] (In Japanese) Gendai Fainansu 22: 3-23

Kudô, Yasushi, 2005, "Shohoteki na murikai no hôchi ga sôgofushin wo zôka saseteiru [Doing Nothing about Basic Misunderstandings Exacerbates Mutual Distrust]," (in Japanese).Ekonomisuto November 22: $32-35$

Kumar, Alok, and Charles M.C. Lee, 2006, "Retail Investor Sentiment and Return Comovements," Journal of Finance 61 (5): 2451-2486.

Lee, Charles M.C., Andrei Shleifer, and Richard H. Thaler, 1991, "Investor Sentiment and the Closed-End Fund Puzzle," Journal of Finance 46 (1): 75-109.

MacKinlay, A. Craig, 1997, "Event Studies in Economics and Finance," Journal of Economic Literature 35 (1): 13 - 39.

Martin,Philippe, Thierry Mayer, and Mathias Thoenig, 2008, "Make Trade Not War?" Review of Economic Studies 75 (3): 865 - 900.

Michaels, Guy, and Xiaojia Zhi, 2010, "Freedom Fries," American Economic Journal: Applied Economics 2 (3): 256 - 281.

Morse, Adair, and Sophie Shive, 2010, "Patriotism in Your Portfolio?" Journal of Financial Markets 14 (2): 411-440.

OECD, 2009, Evaluation of Agricultural Policy Reforms in Japan.

Qian, Yi, 2011, “Counterfeiters: Foes or Friends," Working Paper, Kellogg School of Management, Northwestern University. 
Stambaugh Robert, Jianfeng Yu, and Yu Yuan, 2012, "The Short of It: Investor Sentiment and Anomalies," Journal of Financial Economics 104 (2): 288-302.

Teoh, Siew Hong, Ivo Welch, and C. Paul Wazzan, 1999, "The Effect of Socially Activist Investment Policies on the Financial Markets: Evidence from the South African Boycott," Journal of Business 72 (1): 35 - 89.

U.S.-China Economic and Security Review Commission, 2011, An Analysis of StateOwned Enterprises and State Capitalism in China.

Wang, Fenghua, and Yexiao Xu, 2005, "What Determines Chinese Stock Returns," Financial Analysts Journal 60 (6): 65 - 77.

Weiss, Jessica Chen, 2008, "Powerful Patriots: Nationalism, Diplomacy, and Strategic Logic of Anti-Foreign Protest in China," Ph.D. Dissertation, University of California, San Diego.

Yu, Cherry Jie, 2011, "Firms with Chinese Characteristics: The Role of Companies in Chinese Foreign Policy," Working Paper, London School of Economics and Political Science. 
Figure 1a: Coefficient on Fraction_China_Sales for Japanese firms in CARs regressions around

Textbook Event (April 5, 2005 to April 28, 2005)

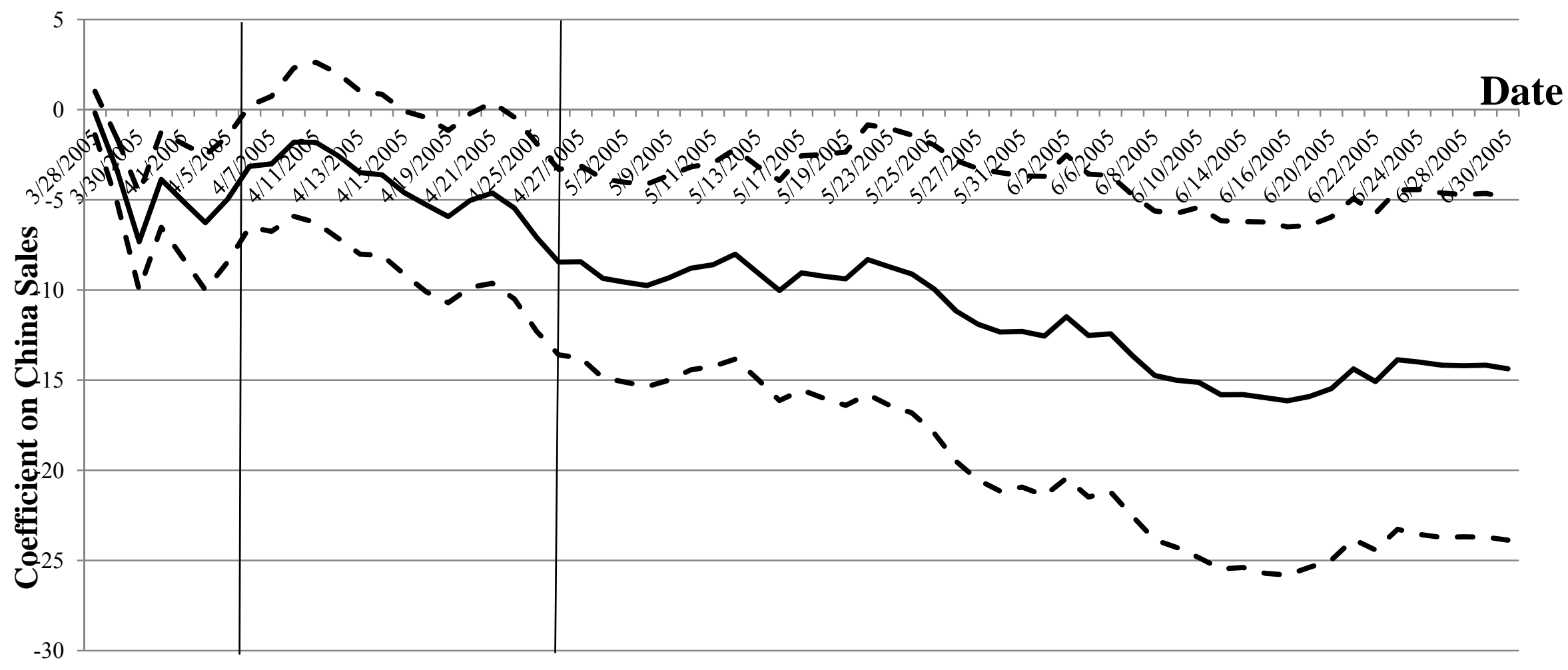

Notes: The solid line shows the coefficients on Fraction_China_Sales from the equation CAR_Textbook $k_{i}=\alpha+\beta_{1}$ Fraction_China_Sales $_{i}+\boldsymbol{\beta}_{2}$ Controls $_{i}+\varepsilon_{i}$, utilizing event windows that begin a week prior to the date we have set as the start of each event, and continuing for two months following each event. That is, each point represents a regression coefficient where the outcome variable is cumulative abnormal returns over the window [-7, date]. Broken lines show [0.05, 0.95] confidence intervals around the coefficient estimates. 
Figure 1b: Coefficient on Fraction_China_Sales for Japanese firms in CARs regressions around Senkaku Event (September 7, 2010 to October 29, 2010)

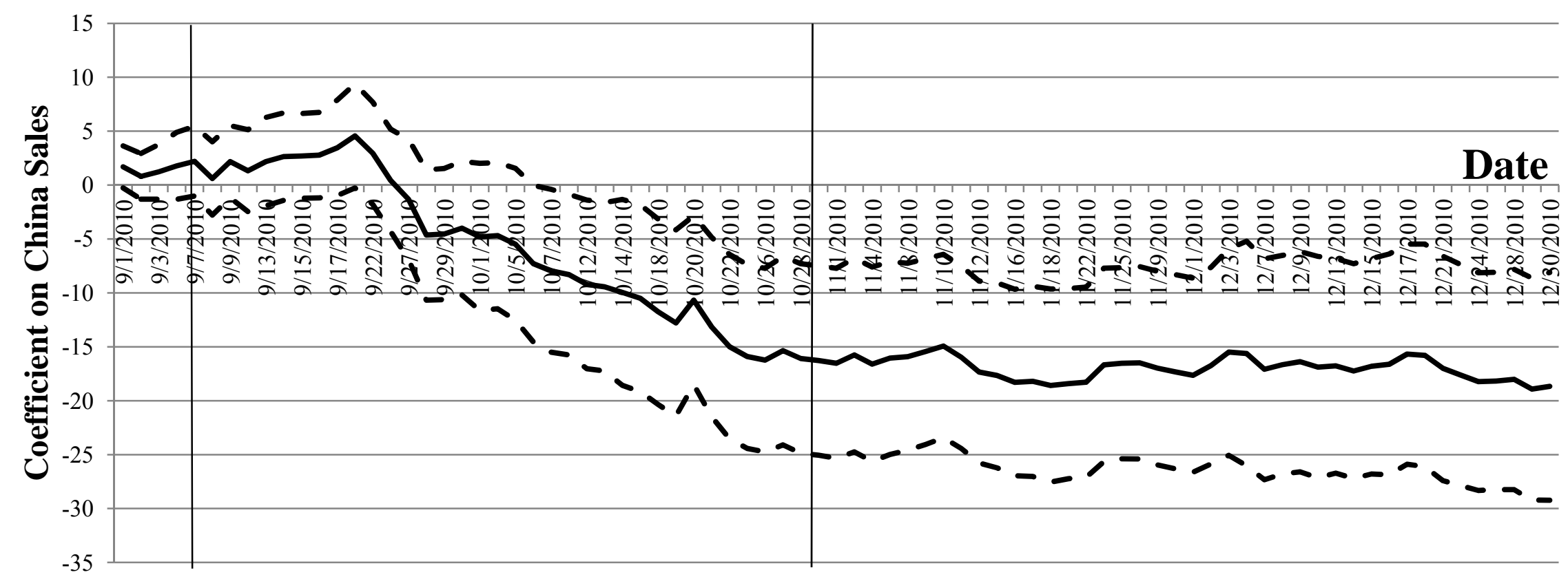

Notes: The solid line shows the coefficients on Fraction_China_Sales from the equation CAR_Senkaku $u_{i}=\alpha+\beta_{1}$ Fraction_China_Sales $_{i}+\boldsymbol{\beta}_{2}$ Controls $_{i}+\varepsilon_{i}$, utilizing event windows that begin a week prior to the date we have set as the start of each event, and continuing for two months following each event. That is, each point represents a regression coefficient where the outcome variable is cumulative abnormal returns over the window [-7, date]. Broken lines show [0.05, 0.95] confidence intervals around the coefficient estimates. 
Figure 1c: Coefficient on Fraction_Japan_Exports for Chinese firms in CARs regressions around

Textbook Event (April 5, 2005 to April 28, 2005)

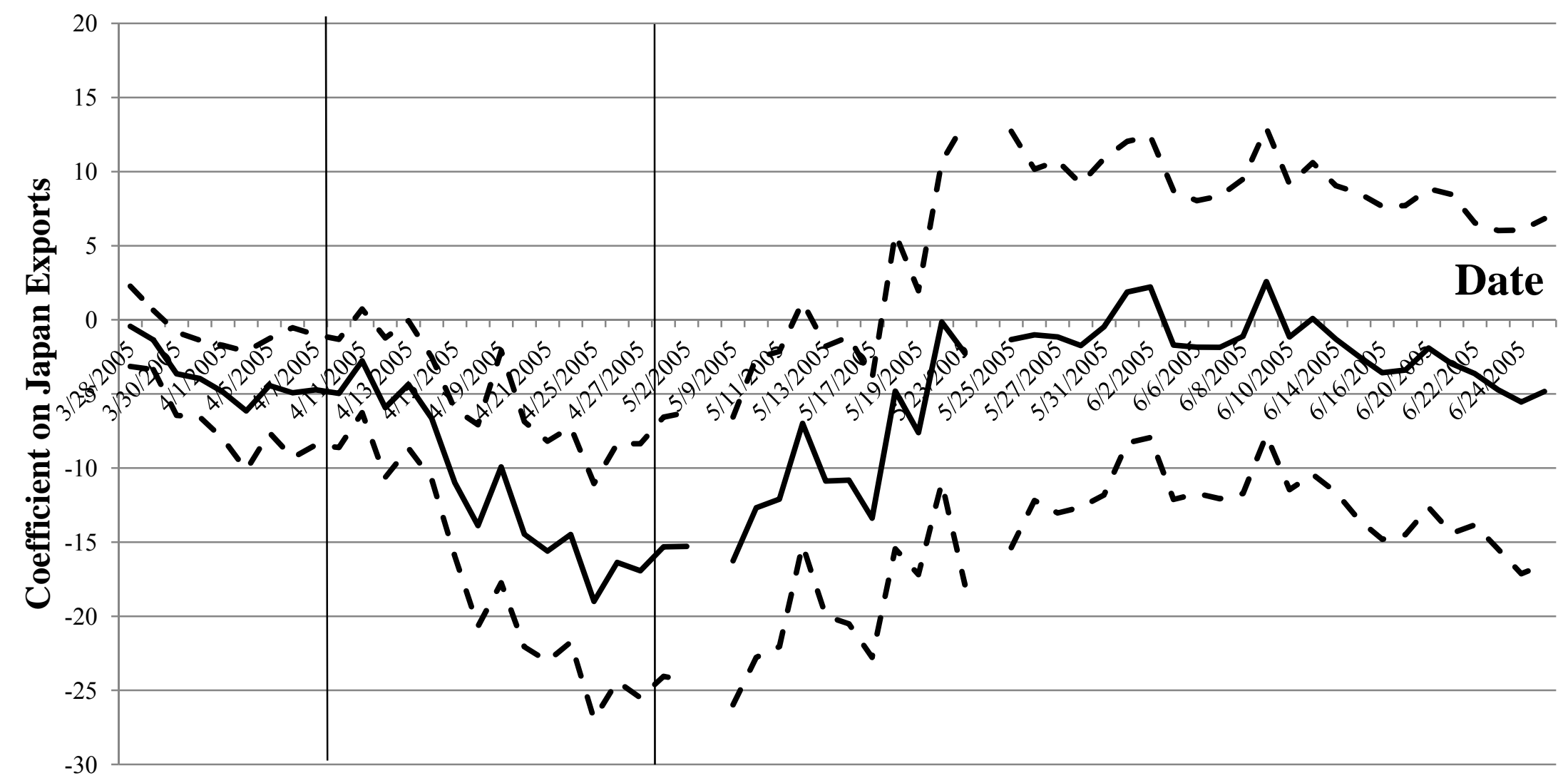

Notes: The solid line shows the coefficients on Fraction_Japan_Exports from the equation CAR_Textbook $k_{i}=\alpha+\beta_{1}$ Fraction_Japan_Exports $_{i}+\boldsymbol{\beta}_{2}$ Controls $_{i}+\varepsilon_{i}$, utilizing event windows that begin a week prior to the date we have set as the start of each event, and continuing for two months following each event. That is, each point represents a regression coefficient where the outcome variable is cumulative abnormal returns over the window [-7, date]. Broken lines show [0.05, 0.95] confidence intervals around the coefficient estimates. 
Figure 1d: Coefficient on Fraction_Japan_Exports for Chinese firms in CARs regressions around

Senkaku Event (September 7, 2010 to October 29, 2010)

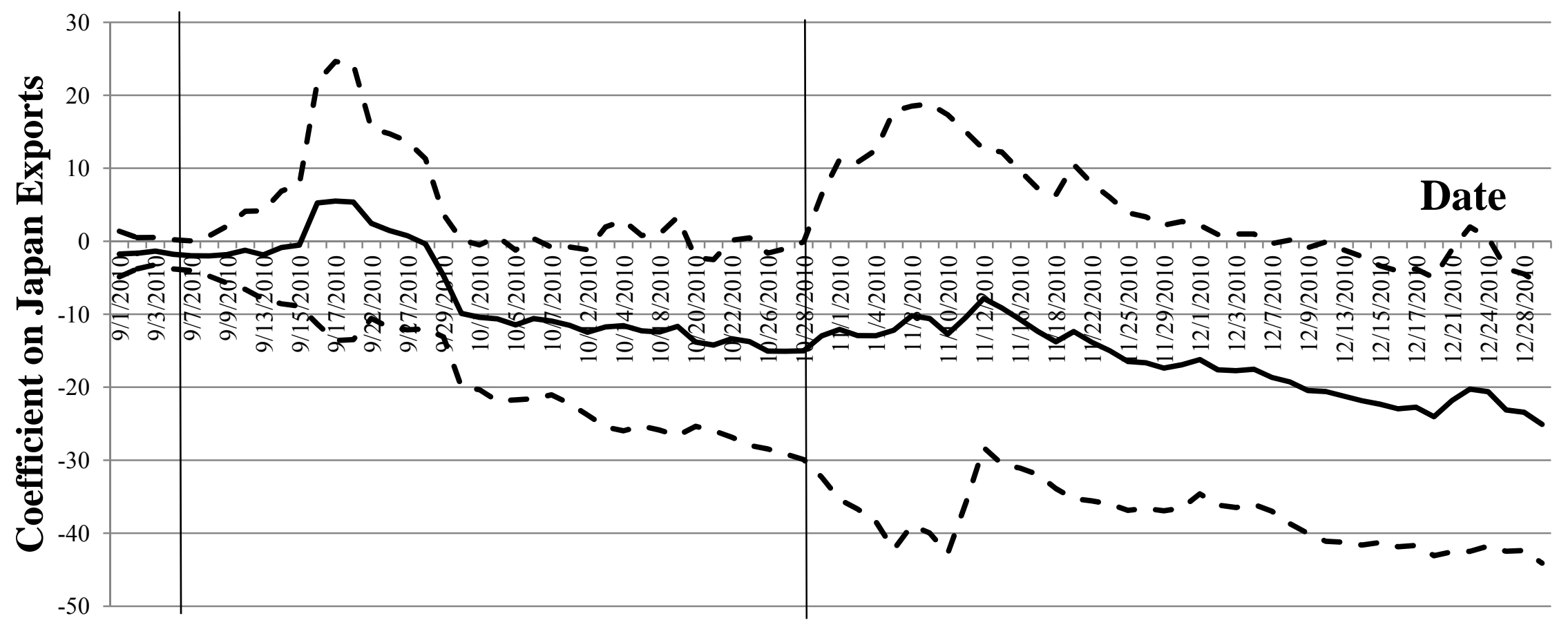

Notes: The solid line shows the coefficients on Fraction_Japan_Exports from the equation CAR_Senkaku $u_{i}=\alpha+\beta_{1}$ Fraction_Japan_Exports $_{i}+\boldsymbol{\beta}_{2}$ Controls $_{i}+\varepsilon_{i}$, utilizing event windows that begin a week prior to the date we have set as the start of each event, and continuing for two months following each event. That is, each point represents a regression coefficient where the outcome variable is cumulative abnormal returns over the window [-7, date]. Broken lines show [0.05, 0.95] confidence intervals around the coefficient estimates. 
Table 1: Summary statistics

\begin{tabular}{|c|c|c|c|c|}
\hline \multicolumn{5}{|c|}{ Panel A: Japanese firms } \\
\hline Variable & Mean & Median & SD & Obs \\
\hline \multicolumn{5}{|c|}{ Event Year: 2005 - Japanese listed firms } \\
\hline TotalAssets (Million Japanese $¥$ ) & 361,570 & 60,615 & $1,288,634$ & 838 \\
\hline (Million U.S. \$ & 3,435 & 576 & 12,243 & ) \\
\hline TotalSales (Million Japanese $¥$ ) & 464,116 & 72,621 & $1,666,269$ & 846 \\
\hline (Million U.S. \$ & 4,409 & 690 & 15,831 & ) \\
\hline Fraction_China_Sales & 0.064 & 0.024 & 0.096 & 846 \\
\hline Fraction_China_Assets & 0.055 & 0.020 & 0.090 & 838 \\
\hline Fraction_Others_Sales & 0.153 & 0.121 & 0.142 & 846 \\
\hline Fraction_China_Empl & 0.155 & 0.081 & 0.193 & 489 \\
\hline $\log (1+$ Tobin’s Q) & 0.940 & 0.873 & 0.411 & 807 \\
\hline Leverage & 0.472 & 0.469 & 0.207 & 834 \\
\hline CAR_Textbook (\%) & -5.816 & -6.356 & 5.813 & 810 \\
\hline Fraction_Indiv_Japan & 0.010 & 0.000 & 0.050 & 846 \\
\hline Fraction_China_Empl & 0.155 & 0.081 & 0.193 & 489 \\
\hline Consumer_Intensity & 0.188 & 0.000 & 0.391 & 846 \\
\hline \multicolumn{5}{|c|}{ Event Year: 2010 - Japanese listed firms } \\
\hline TotalAssets (Million Japanese $¥$ ) & 382,867 & 60,872 & $1,466,688$ & 896 \\
\hline (Million U.S. \$ & 4,685 & 745 & 17,946 & ) \\
\hline TotalSales (Million Japanese $¥$ ) & 400,108 & 58,493 & $1,424,914$ & 920 \\
\hline (Million U.S. \$ & 4,896 & 716 & 17,435 & ) \\
\hline Fraction_China_Sales & 0.081 & 0.048 & 0.105 & 920 \\
\hline Fraction_China_Assets & 0.074 & 0.040 & 0.135 & 896 \\
\hline Fraction_Others_Sales & 0.145 & 0.106 & 0.147 & 920 \\
\hline Fraction_China_Empl & 0.165 & 0.107 & 0.184 & 566 \\
\hline $\log (1+$ Tobin's Q $)$ & 0.700 & 0.647 & 0.324 & 886 \\
\hline Leverage & 0.459 & 0.452 & 0.239 & 894 \\
\hline CAR_Senkaku (\%) & -3.689 & -3.622 & 11.169 & 905 \\
\hline Fraction_Indiv_Japan & 0.012 & 0.000 & 0.051 & 895 \\
\hline Fraction_China_Empl & 0.165 & 0.107 & 0.184 & 566 \\
\hline Consumer_Intensity & 0.179 & 0.000 & 0.384 & 920 \\
\hline
\end{tabular}


Panel B: Chinese firms

\begin{tabular}{lrrrr}
\hline Variable & Mean & Median & SD & Obs \\
\hline Event Year: 2005 - Chinese listed firms & & & & \\
Total Assets (Million RMB ¥) & 5,080 & 1,430 & 32,800 & 1058 \\
\multicolumn{1}{c}{ (Million U.S. \$ } & 762 & 214 & 4,919 & ) \\
Fraction_Japan_Exports & 0.003 & 0.000 & 0.033 & 1058 \\
Fraction_Others_Exports & 0.0268 & 0.000 & 0.099 & 1058 \\
Drugs_and_Food & 0.134 & 0.000 & 0.341 & 1058 \\
Log(1+Tobin’s Q) & 0.942 & 0.882 & 0.238 & 1037 \\
Leverage & 0.540 & 0.503 & 0.606 & 1058 \\
CAR_Textbook (\%) & -3.833 & -3.941 & 12.188 & 1058 \\
Fraction_Indiv_China & 0.925 & 0.987 & 0.139 & 1058 \\
Consumer_Intensity & 0.388 & 0.000 & 0.488 & 1058 \\
\hline Event Year: 2010 - Chinese listed firms & & & & \\
Total Assets (Million RMB $¥)$ & 14,000 & 2,490 & 104,000 & 1025 \\
$\quad$ (Million U.S. \$ & 1,692 & 301 & 12,566 & ) \\
Fraction_Japan_Exports & 0.003 & 0.000 & 0.033 & 1025 \\
Fraction_Others_Exports & 0.027 & 0.000 & 0.100 & 1025 \\
Drugs_and_Food & 0.134 & 0.000 & 0.340 & 1024 \\
Log(1+Tobin’s Q) & 1.327 & 1.207 & 0.572 & 1024 \\
Leverage & 0.815 & 0.546 & 4.752 & 1024 \\
CAR_Senkaku (\%) & 1.485 & -0.098 & 13.710 & 1024 \\
Fraction_Indiv_China & 0.683 & 0.705 & 0.213 & 1025 \\
Consumer_Intensity & 0.392 & 0.000 & 0.488 & 1024 \\
\hline \hline
\end{tabular}

Notes: Total Assets is total assets of the listed firm; Total Sales is total sales; Fraction_China_Sales is the ratio of sales in China to total sales for the sample of Japanese firms; Fraction_China_Assets is the ratio of total assets in China to total assets for the sample of Japanese firms; Fraction_Others_Sales is the ratio of sales in all the foreign countries other than China to total sales, for Japanese firms in our sample; Fraction_China_Empl is the ratio of Chinese employees in China to total employees of Japanese firms; Fraction_Japan_Exports is the ratio of total exports to Japan to total sales for the sample of Chinese firms; Fraction_Others_Exports is the ratio of exports to all foreign countries other than Japan to total sales, for the sample of Chinese firms; Drugs_and_Food is a dummy variable that is equal to 1 for Chinese firms in Foods, Drugs, or Agriculture; Leverage is the ratio of total liabilities to total assets; $\log (1+$ Tobin's $Q)$ is the log value of one plus Tobin's Q; CAR_Textbook is the cumulative abnormal return during the Textbook Event (April 5, 2005 to April 28, 2005); CAR_Senkaku is the cumulative abnormal return during the Senkaku Event (September 7, 2010 to October 29, 2010); Fraction_Indiv is the ratio of individual ownership to total outstanding shares; Consumer_Intensity is a dummy variable denoting firms mainly producing consumer-oriented products. In all cases, abnormal return is estimated using a standard Fama-French three-factor model using [-150, -30] trading days as the estimation window. All cumulative abnormal returns are Winsorized at $1 \%$. Exchange rates are as of March 1. 2005 and October 1, 2010. 
Table 2A: SOE-concentration and consumer-intensity

\begin{tabular}{|c|c|c|c|c|c|}
\hline $\begin{array}{l}\text { Nikkei } \\
\text { Industry } \\
\text { Code }\end{array}$ & Nikkei Industry Name & $\begin{array}{c}\text { SOE_Intensity } \\
\text { (Chinese Firms) }\end{array}$ & $\begin{array}{c}\text { China } \\
\text { NBS } \\
\text { Industry } \\
\text { Code } \\
\end{array}$ & $\begin{array}{c}\text { Consumer_Intensity } \\
\text { (Japanese Firms) }\end{array}$ & $\begin{array}{c}\text { Percentage } \\
\text { (Japanese } \\
\text { Firms) }\end{array}$ \\
\hline 1 & Foods & 0.0537 & 1400 & 0.7508 & 2.04 \\
\hline 3 & Textile Products & 0.0488 & 1700 & 0.1250 & 2.38 \\
\hline 5 & Pulp \& Paper & 0.0731 & 2200 & 0.0000 & 0.62 \\
\hline 7 & Chemicals & 0.1106 & 2600 & 0.0802 & 9.17 \\
\hline 9 & Drugs & 0.0602 & 2700 & 0.5686 & 1.47 \\
\hline 11 & Petroleum & 0.1534 & 2500 & 0.0000 & 0.57 \\
\hline 13 & Rubber Products & 0.0557 & 2900 & 0.1213 & 1.87 \\
\hline 15 & Stone, Clay \& Glass Products & 0.0895 & 3100 & 0.0500 & 2.27 \\
\hline 17 & Iron \& Steel & 0.1413 & 3200 & 0.0000 & 1.42 \\
\hline 19 & Nonferrous Metal \& Metal Products & 0.1200 & 3300 & 0.0398 & 4.25 \\
\hline 21 & Machinery & 0.0815 & 3500 & 0.0265 & 12.80 \\
\hline 23 & Electric \& Electronic Equipment & 0.0813 & 3900 & 0.1432 & 21.35 \\
\hline 25 & Shipbuilding \& Repairing & 0.0918 & 3700 & 0.0000 & 0.23 \\
\hline 27 & Motor Vehicles\& AutoParts & 0.0918 & 3700 & 0.1653 & 7.19 \\
\hline 29 & Transportation Equipment & 0.0918 & 3700 & 0.0625 & 0.85 \\
\hline 31 & Precision Equipment & 0.0466 & 4100 & 0.1806 & 4.08 \\
\hline 33 & Other Manufacturing & 0.1365 & 2300 & 0.4980 & 4.42 \\
\hline 37 & Mining & 0.2638 & 1100 & 0.0000 & 0.34 \\
\hline 41 & Construction & 0.2616 & $\mathrm{E}$ & 0.0729 & 1.59 \\
\hline 43 & Wholesale Trade & 0.2038 & 6300 & 0.1567 & 8.27 \\
\hline 45 & Retail Trade & 0.1115 & 6500 & 1.0000 & 1.43 \\
\hline 52 & Credit \& Leasing & 0.2434 & $\mathrm{~L}$ & 0.2833 & 0.60 \\
\hline 53 & Real Estate & 0.0982 & 7200 & 0.0000 & 0.12 \\
\hline 55 & Railroad Transportation & 0.3218 & 5300 & 0.5000 & 0.06 \\
\hline 57 & Trucking & 0.2041 & 5200 & 0.3429 & 0.68 \\
\hline 59 & Sea Transportation & 0.4619 & 5400 & 0.0000 & 0.91 \\
\hline 63 & Warehousing \& Harbor Transportation & 0.5097 & 5800 & 0.0000 & 0.96 \\
\hline 65 & Communication Services & 0.1260 & $\mathrm{G}$ & 1.0000 & 0.24 \\
\hline 71 & Services & 0.3871 & 8900 & 0.5122 & 5.72 \\
\hline
\end{tabular}

Notes: For each industry in the Nikkei Industrial Code (at the 2-digit level), we find the corresponding Chinese industry code adopted by National Bureau of Statistics in China. SOE_Intensity is the average value of the ratio of total sales by state-owned firms to total sales in each industry in China in 2004. Sales data by ownership in each industry come from China Economic Census 2004, which covers all firms in China. Consumer Intensity is a dummy variable that is equal to 1 if the firm mainly produces consumer-oriented products, and we use its average value in 2004. Figures for 2008 (unreported) are similar. 
Table 2B: Consumer-intensity: Chinese listed firms

\begin{tabular}{|c|c|c|c|}
\hline $\begin{array}{c}\text { CSRC } \\
\text { Industry } \\
\text { Code }\end{array}$ & Industry Name & $\begin{array}{c}\text { Consumer_Intensity } \\
\text { (Chinese Firms) }\end{array}$ & $\begin{array}{c}\text { Percentage } \\
\text { (Chinese } \\
\text { Firms) } \\
\end{array}$ \\
\hline A0 & Agriculture & 0.2830 & 2.54 \\
\hline B0 & Mining & 0.0571 & 1.68 \\
\hline $\mathrm{C} 0$ & Foods and drinks & 0.8333 & 4.03 \\
\hline $\mathrm{C} 1$ & Textile, Apparel and Fur & 0.6170 & 4.51 \\
\hline $\mathrm{C} 2$ & Lumber and furniture & 0.5000 & 0.19 \\
\hline $\mathrm{C} 3$ & Paper and printing & 0.2609 & 1.10 \\
\hline $\mathrm{C} 4$ & Oil, Chemicals and Plastics & 0.1084 & 9.75 \\
\hline $\mathrm{C} 5$ & Electronics & 0.1786 & 2.69 \\
\hline C6 & Metal and non-metal & 0.0983 & 8.31 \\
\hline $\mathrm{C} 7$ & Machinery, apparatus and devices & 0.1636 & 13.20 \\
\hline $\mathrm{C} 8$ & Medical products and biologicals & 0.7547 & 7.63 \\
\hline C9 & Other Manufacturing & 0.1111 & 0.86 \\
\hline D0 & Gas, water and electricity production and supply & 0.3636 & 5.28 \\
\hline E0 & Construction & 0.0816 & 2.35 \\
\hline F0 & Transportation & 0.3235 & 1.63 \\
\hline $\mathrm{F} 1$ & Transportation: complementary & 0.4667 & 2.88 \\
\hline $\mathrm{F} 2$ & Warehousing & 0.0000 & 0.10 \\
\hline G8 & Information technology & 0.2846 & 5.90 \\
\hline $\mathrm{H} 0$ & Wholesale Trade & 0.3636 & 1.06 \\
\hline $\mathrm{H} 1$ & Retail Trade & 0.7400 & 4.80 \\
\hline $\mathrm{H} 2$ & Business agencies & 0.3000 & 1.92 \\
\hline $\mathrm{I} 0$ & Banks & 1.0000 & 0.48 \\
\hline $\mathrm{I} 2$ & Securities and futures & 1.0000 & 0.67 \\
\hline $\mathrm{I} 3$ & Trust & 1.0000 & 0.10 \\
\hline $\mathrm{J} 0$ & Real Estate Developing & 0.9520 & 6.00 \\
\hline K0 & Public facilities & 0.5385 & 1.25 \\
\hline K3 & Catering industry & 0.8333 & 1.73 \\
\hline K9 & Other services & 1.0000 & 0.10 \\
\hline L0 & Publishing & 0.5000 & 0.29 \\
\hline L1 & Broadcasting and Television & 0.7500 & 0.38 \\
\hline L2 & Information service & 0.0000 & 0.19 \\
\hline L9 & Other culture-related industries & 0.0000 & 0.10 \\
\hline $\mathrm{M}$ & Miscellaneous/Unclassified & 0.2366 & 6.29 \\
\hline
\end{tabular}

Notes: This table reports the average of Consumer_Intensity for each Chinese Industry (used by the SEC in China) in 2004. Consumer Intensity is a dummy variable that is equal to 1 if the firm is mainly producing consumer-oriented products, and we use its average value in 2004. Figures for 2008 (unreported) are similar. 
Table 3: Regressions of abnormal event returns on China Sales Ratio/China Assets Ratio: Japanese firms

\begin{tabular}{|c|c|c|c|c|c|c|c|c|c|c|}
\hline Dependent variable: & $\begin{array}{c}(1) \\
\text { CAR_- } \\
\text { Textbook } \\
\end{array}$ & $\begin{array}{c}(2) \\
\text { CAR_- } \\
\text { Textbook } \\
\end{array}$ & $\begin{array}{c}(3) \\
\text { CAR_- } \\
\text { Textbook } \\
\end{array}$ & $\begin{array}{c}\text { (4) } \\
\text { CAR_- } \\
\text { Textbook } \\
\end{array}$ & $\begin{array}{c}(5) \\
\text { CAR_- } \\
\text { Senkaku } \\
\end{array}$ & $\begin{array}{c}\text { (6) } \\
\text { CAR_- } \\
\text { Senkaku } \\
\end{array}$ & $\begin{array}{c}(7) \\
\text { CAR_- } \\
\text { Senkaku } \\
\end{array}$ & $\begin{array}{c}(8) \\
\text { CAR_- } \\
\text { Senkaku } \\
\end{array}$ & $\begin{array}{c}(9) \\
\text { CAR_ } \\
\text { Pooled } \\
\end{array}$ & $\begin{array}{c}(10) \\
\text { CAR } \\
\text { Pooled } \\
\end{array}$ \\
\hline Fraction_China_Sales & $\begin{array}{c}-7.487 * * * \\
(1.899)\end{array}$ & $\begin{array}{c}-8.063 * * * \\
(1.961)\end{array}$ & $\begin{array}{c}-7.379 * * * \\
(2.257)\end{array}$ & & $\begin{array}{c}-18.191 * * * \\
(4.354)\end{array}$ & $\begin{array}{c}-18.136^{* * *} \\
(4.501)\end{array}$ & $\begin{array}{c}-21.645^{* * *} \\
(4.847)\end{array}$ & & $\begin{array}{c}-6.698 * * * \\
(2.305)\end{array}$ & \\
\hline Fraction_China_Assets & & & & $\begin{array}{c}-6.544 * * * \\
(2.435)\end{array}$ & & & & $\begin{array}{c}-24.459 * * * \\
(4.912)\end{array}$ & & $\begin{array}{c}-4.908 * \\
(2.508)\end{array}$ \\
\hline Fraction_Others_Sales & & $\begin{array}{c}0.694 \\
(1.497)\end{array}$ & $\begin{array}{c}1.815 \\
(1.680)\end{array}$ & & & $\begin{array}{l}-0.718 \\
(2.835)\end{array}$ & $\begin{array}{l}-0.432 \\
(2.993)\end{array}$ & & $\begin{array}{c}0.496 \\
(1.814)\end{array}$ & \\
\hline Log(TotalAssets) & $\begin{array}{c}-0.687 * * * \\
(0.138)\end{array}$ & $\begin{array}{c}-0.638 * * * \\
(0.139)\end{array}$ & $\begin{array}{c}-0.616^{* * *} \\
(0.133)\end{array}$ & & $\begin{array}{c}0.296 \\
(0.278)\end{array}$ & $\begin{array}{c}0.367 \\
(0.300)\end{array}$ & $\begin{array}{c}0.282 \\
(0.293)\end{array}$ & $\begin{array}{l}-0.125 \\
(0.170)\end{array}$ & $\begin{array}{l}-0.129 \\
(0.169)\end{array}$ & $\begin{array}{l}-0.159 \\
(0.162)\end{array}$ \\
\hline Log(1+Tobin's Q) & & $\begin{array}{c}-1.922 * * * \\
(0.676)\end{array}$ & $\begin{array}{c}-1.832 * * * \\
(0.682)\end{array}$ & & & $\begin{array}{c}-4.082 * * \\
(1.783)\end{array}$ & $\begin{array}{c}-3.630 * * \\
(1.734)\end{array}$ & $\begin{array}{c}-2.549 * * * \\
(0.801)\end{array}$ & $\begin{array}{c}-2.621 * * * \\
(0.810)\end{array}$ & $\begin{array}{c}-2.419 * * * \\
(0.794)\end{array}$ \\
\hline Leverage & & $\begin{array}{c}-2.575 * * \\
(1.184)\end{array}$ & $\begin{array}{c}-2.619 * * \\
(1.153)\end{array}$ & & & $\begin{array}{l}-0.702 \\
(2.102)\end{array}$ & $\begin{array}{l}-0.270 \\
(2.040)\end{array}$ & $\begin{array}{l}-1.401 \\
(1.339)\end{array}$ & $\begin{array}{l}-1.543 \\
(1.343)\end{array}$ & $\begin{array}{l}-1.303 \\
(1.307)\end{array}$ \\
\hline Fraction_China_Sales $\times$ Y2010 & & & & & & & & & $\begin{array}{c}-15.689 * * * \\
(5.069)\end{array}$ & \\
\hline Fraction_China_Assets $\times$ Y 2010 & & & & & & & & & & $\begin{array}{c}-20.688^{* * *} \\
(5.171)\end{array}$ \\
\hline Constant & $\begin{array}{c}-5.347 * * * \\
(0.244) \\
\end{array}$ & $\begin{array}{c}2.337 \\
(1.605) \\
\end{array}$ & $\begin{array}{c}4.538 * * * \\
(1.583)\end{array}$ & $\begin{array}{c}4.409 * * * \\
(1.579) \\
\end{array}$ & $\begin{array}{c}-2.225^{* * *} \\
(0.486) \\
\end{array}$ & $\begin{array}{c}-5.424 * \\
(3.231) \\
\end{array}$ & $\begin{array}{l}-2.767 \\
(3.290) \\
\end{array}$ & $\begin{array}{l}-2.396 \\
(3.246) \\
\end{array}$ & $\begin{array}{c}0.674 \\
(1.947) \\
\end{array}$ & $\begin{array}{c}0.741 \\
(1.922) \\
\end{array}$ \\
\hline Sample & \multicolumn{4}{|c|}{2005 Textbook Event } & \multicolumn{4}{|c|}{2010 Senkaku Event } & Pooled & Pooled \\
\hline Industry Fixed Effects & & & Included & Included & & & Included & Included & & \\
\hline Industry $\times$ Year Fixed Effects & & & & & & & & & Included & Included \\
\hline Number of Observations & 810 & 804 & 800 & 800 & 905 & 882 & 878 & 878 & 1,678 & 1,678 \\
\hline R-squared & 0.012 & 0.044 & 0.085 & 0.079 & 0.027 & 0.027 & 0.048 & 0.058 & 0.062 & 0.070 \\
\hline
\end{tabular}

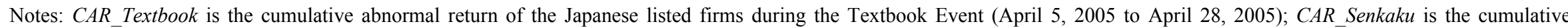

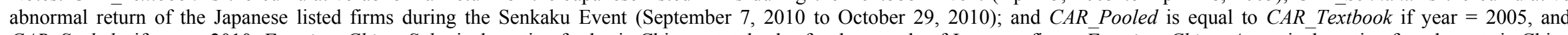

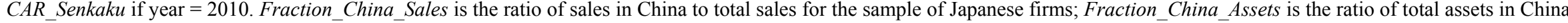

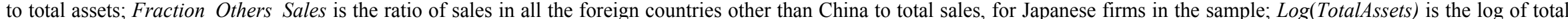

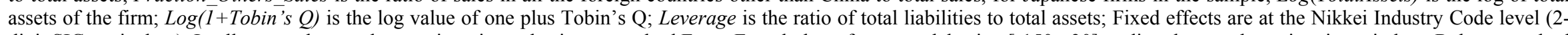

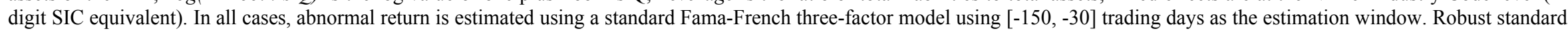
errors are in parentheses. Standard errors are clustered at the firm level in pooled regressions. *, **, and *** indicate significance at the $10 \%, 5 \%$, and $1 \%$ level, respectively. 
Table 4 : Regressions of abnormal event returns on export to Japan: Chinese firms

\begin{tabular}{|c|c|c|c|c|c|c|c|c|}
\hline Dependent variable: & $\begin{array}{c}\text { (1) } \\
\text { CAR_- } \\
\text { Textbook }\end{array}$ & $\begin{array}{c}\text { (2) } \\
\text { CAR_- } \\
\text { Textbook }\end{array}$ & $\begin{array}{c}\text { (3) } \\
\text { CAR_- } \\
\text { Textbook } \\
\end{array}$ & $\begin{array}{c}\text { (4) } \\
\text { CAR_- } \\
\text { Senkaku }\end{array}$ & $\begin{array}{c}\text { (5) } \\
\text { CAR_- } \\
\text { Senkaku }\end{array}$ & $\begin{array}{c}(6) \\
\text { CAR_- } \\
\text { Senkaku } \\
\end{array}$ & $\begin{array}{l}(7) \\
\text { CAR_- } \\
\text { Pooled } \\
\end{array}$ & $\begin{array}{l}(8) \\
\text { CAR } \\
\text { Pooled } \\
\end{array}$ \\
\hline Fraction_Japan_Exports & $\begin{array}{c}-8.745^{* *} \\
(3.791)\end{array}$ & $\begin{array}{c}-17.079 * * \\
(7.784)\end{array}$ & $\begin{array}{c}-42.747 * * \\
(20.582)\end{array}$ & $\begin{array}{c}-11.454^{*} \\
(6.805)\end{array}$ & $\begin{array}{l}-13.279 \\
(8.779)\end{array}$ & $\begin{array}{l}-13.980 \\
(8.734)\end{array}$ & $\begin{array}{l}-32.155^{*} \\
(17.445)\end{array}$ & $\begin{array}{l}-48.937 * \\
(28.881)\end{array}$ \\
\hline Fraction_Others_Exports & & $\begin{array}{c}13.331^{* * *} \\
(4.884)\end{array}$ & $\begin{array}{c}13.571^{* * *} \\
(4.784)\end{array}$ & & $\begin{array}{c}0.361 \\
(3.965)\end{array}$ & $\begin{array}{c}0.354 \\
(3.969)\end{array}$ & $\begin{array}{l}6.858 * * \\
(3.043)\end{array}$ & $\begin{array}{c}1.447 \\
(5.407)\end{array}$ \\
\hline Log(TotalAssets) & & $\begin{array}{c}2.410 * * * \\
(0.416)\end{array}$ & $\begin{array}{c}2.878 * * * \\
(0.498)\end{array}$ & & $\begin{array}{c}0.291 \\
(0.314)\end{array}$ & $\begin{array}{l}-0.067 \\
(0.430)\end{array}$ & $\begin{array}{c}1.170^{* * *} \\
(0.320)\end{array}$ & $\begin{array}{l}-0.341 \\
(1.315)\end{array}$ \\
\hline $\log (1+$ Tobin's $Q)$ & & & $\begin{array}{l}3.997 * \\
(2.323)\end{array}$ & & & $\begin{array}{l}-1.051 \\
(1.261)\end{array}$ & $\begin{array}{c}0.932 \\
(1.084)\end{array}$ & $\begin{array}{l}-2.332 \\
(3.223)\end{array}$ \\
\hline Leverage & & & $\begin{array}{l}-1.770 \\
(1.236)\end{array}$ & & & $\begin{array}{l}-0.039 \\
(0.100)\end{array}$ & $\begin{array}{l}-0.104 \\
(0.095)\end{array}$ & $\begin{array}{l}-0.312 \\
(0.302)\end{array}$ \\
\hline Fraction_Japan_Exports $\times$ Y 2010 & & & & & & & $\begin{array}{c}18.604 \\
(17.468)\end{array}$ & $\begin{array}{c}32.996 \\
(27.539)\end{array}$ \\
\hline Constant & $\begin{array}{c}-3.804 * * * \\
(0.377)\end{array}$ & $\begin{array}{c}-55.164 * * * \\
(8.837) \\
\end{array}$ & $\begin{array}{c}-67.812 * * * \\
(11.741)\end{array}$ & $\begin{array}{c}1.524 * * * \\
(0.431)\end{array}$ & $\begin{array}{l}-4.789 \\
(6.842)\end{array}$ & $\begin{array}{c}4.414 \\
(10.483) \\
\end{array}$ & $\begin{array}{c}-27.365^{* * *} \\
(7.620) \\
\end{array}$ & $\begin{array}{r}10.598 \\
(31.229) \\
\end{array}$ \\
\hline Sample & \multicolumn{3}{|c|}{2005 Textbook Event } & \multicolumn{3}{|c|}{2010 Senkaku Event } & Pooled & Pooled \\
\hline $\begin{array}{l}\text { Fixed Effects } \\
\text { Number of Observations } \\
\text { R-squared }\end{array}$ & $\begin{array}{c}\text { Year } \\
1,058 \\
-0.000\end{array}$ & $\begin{array}{c}\text { Year } \\
1,058 \\
0.133\end{array}$ & $\begin{array}{c}\text { Industry \& Year } \\
1,036 \\
0.141\end{array}$ & $\begin{array}{c}\text { Year } \\
1,024 \\
-0.000\end{array}$ & $\begin{array}{l}\text { Year } \\
1,023 \\
0.162\end{array}$ & $\begin{array}{c}\text { Industry \& Year } \\
1,023 \\
0.162\end{array}$ & $\begin{array}{l}\text { Indu } \\
2,059 \\
0.095\end{array}$ & $\begin{array}{l}\text { Year } \\
254 \\
0.034\end{array}$ \\
\hline
\end{tabular}

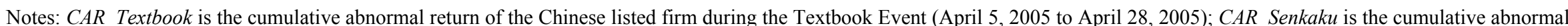

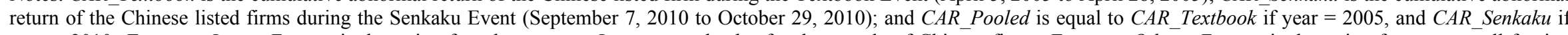

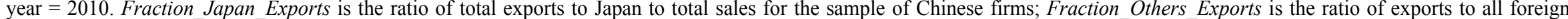

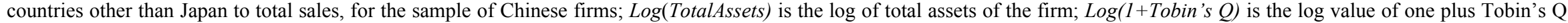

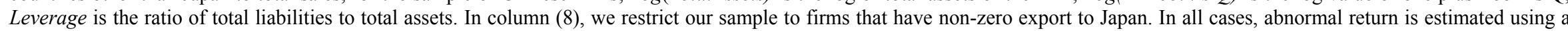

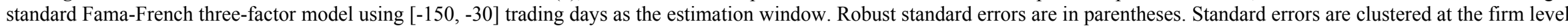
in pooled regressions. ${ }^{*}, *$, and $* * *$ indicate significance at the $10 \%, 5 \%$, and $1 \%$ level, respectively. 


\title{
Table 5: Identifying the mechanisms (Japanese firms): Government intervention or consumer sentiment?
}

\author{
(1) \\ (2)
}

(3)

(4)

Dependent Variable: CAR_Pooled

\begin{tabular}{|c|c|c|c|c|}
\hline Fraction_China_Sales & $\begin{array}{c}7.742 \\
(5.462)\end{array}$ & $\begin{array}{c}-6.862 * * * \\
(2.355)\end{array}$ & $\begin{array}{l}-5.165 * \\
(3.099)\end{array}$ & $\begin{array}{c}2.833 \\
(6.258)\end{array}$ \\
\hline Fraction_China_Sales $\times$ SOE_Intensity & $\begin{array}{c}-109.841 * * * \\
(37.692)\end{array}$ & & & $\begin{array}{l}-62.369 \\
(40.788)\end{array}$ \\
\hline SOE_Intensity & $\begin{array}{c}-3.953 \\
(14.287)\end{array}$ & & & $\begin{array}{c}1.952 \\
(12.583)\end{array}$ \\
\hline $\begin{array}{l}\text { Fraction_China_Sales } \times \\
\text { Consumer_Intensity }\end{array}$ & & $\begin{array}{c}2.873 \\
(7.747)\end{array}$ & & $\begin{array}{c}2.153 \\
(9.000)\end{array}$ \\
\hline Consumer_Intensity & & $\begin{array}{c}0.313 \\
(0.907)\end{array}$ & & $\begin{array}{l}-0.926 \\
(1.111)\end{array}$ \\
\hline Fraction_China_Empl & & & $\begin{array}{l}5.594 * \\
(3.018)\end{array}$ & $\begin{array}{c}2.690 \\
(1.726)\end{array}$ \\
\hline Fraction_Others_Sales & $\begin{array}{c}0.990 \\
(1.858)\end{array}$ & $\begin{array}{c}0.444 \\
(1.835)\end{array}$ & $\begin{array}{l}2.915^{*} \\
(1.763)\end{array}$ & $\begin{array}{c}0.337 \\
(2.201)\end{array}$ \\
\hline Log(TotalAssets) & $\begin{array}{l}-0.132 \\
(0.169)\end{array}$ & $\begin{array}{l}-0.150 \\
(0.174)\end{array}$ & $\begin{array}{l}-0.304 \\
(2.106)\end{array}$ & $\begin{array}{c}0.225 \\
(0.221)\end{array}$ \\
\hline $\log (1+$ Tobin's Q) & $\begin{array}{c}-2.560 * * * \\
(0.803)\end{array}$ & $\begin{array}{c}-2.629 * * * \\
(0.813)\end{array}$ & $\begin{array}{c}0.195 \\
(0.217)\end{array}$ & $\begin{array}{c}-3.296 * * * \\
(1.017)\end{array}$ \\
\hline Leverage & $\begin{array}{l}-1.596 \\
(1.346)\end{array}$ & $\begin{array}{l}-1.546 \\
(1.340)\end{array}$ & $\begin{array}{c}-3.425^{* * *} \\
(1.025)\end{array}$ & $\begin{array}{l}-1.702 \\
(1.743)\end{array}$ \\
\hline Fraction_China_Sales $\times$ Y 2010 & $\begin{array}{c}-19.922 * * * \\
(5.020)\end{array}$ & $\begin{array}{c}-15.726 * * * \\
(5.061)\end{array}$ & $\begin{array}{c}-12.140 * \\
(6.215)\end{array}$ & $\begin{array}{c}-14.310 * * \\
(6.074)\end{array}$ \\
\hline Constant & $\begin{array}{c}1.002 \\
(2.499) \\
\end{array}$ & $\begin{array}{c}0.856 \\
(2.011) \\
\end{array}$ & $\begin{array}{l}-3.178 \\
(2.432) \\
\end{array}$ & $\begin{array}{l}-3.710 \\
(2.912) \\
\end{array}$ \\
\hline Fixed Effects & \multicolumn{4}{|c|}{ Industry $\times$ Year } \\
\hline Number of Observations & 1,670 & 1,678 & 1,030 & 1,025 \\
\hline R-squared & 0.066 & 0.061 & 0.048 & 0.049 \\
\hline
\end{tabular}

Notes: Dependent variable in all columns is CAR_Pooled, for the sample of Japanese listed firms, which is equal to $C A R \_T e x t b o o k$ for year $=2005$, and CAR_Senkaku for year $=2010$, and CAR_Textbook is the cumulative abnormal return during the Textbook Event (April 5, 2005 to April 28, 2005), and CAR_Senkaku is the cumulative abnormal return during the Senkaku Event (September 7, 2010 to October 29, 2010); Fraction_China_Sales is the ratio of sales in China to total sales for the sample of Japanese firms; $S O E$ Intensity is average value of the ratio of total sales by state-owned firms to total sales in each industry in China; Consumer_Intensity is a dummy variable that is equal to 1 if the firm is mainly producing consumer-oriented products; Fraction_China_Empl is the ratio of Chinese employees in China to total employees of Japanese firms; Fraction_Others_Sales is the ratio of sales in all the foreign countries other than China to total sales, for Japanese firms; $\log ($ TotalAssets) is the log of total assets of the firm; $\log (1+$ Tobin's $Q)$ is the log value of one plus Tobin's Q; Fraction_China_Sales is the ratio of sales in China to total sales for each Japanese firm in the sample; Leverage is the ratio of total liabilities to total assets. Fixed effects are at the Nikkei Industry Code level (2-digit SIC equivalent). In all cases, abnormal return is estimated using a standard Fama-French three-factor model using [-150, -30] trading days as the estimation window. Robust standard errors, clustered at the firm level, are in parentheses. $* * *$, and $* * *$ indicate significance at the $10 \%, 5 \%$, and $1 \%$ level, respectively. 


\section{Table 6: The Long-term Effect on Imports by Chinese State firms versus Private Firms}

\section{(1)}

(2)

(3)

Dependent variable: JPN_Import_Rate

\begin{tabular}{lcccc}
\hline & & & & \\
State & $-0.051^{* * *}$ & $-0.058^{* * *}$ & 0.000 & 0.000 \\
& $(0.004)$ & $(0.006)$ & $(0.000)$ & $(0.000)$ \\
State $\times$ After & -0.007 & $-0.009^{*}$ & $-0.007^{*}$ & $-0.009^{*}$ \\
& $(0.004)$ & $(0.005)$ & $(0.004)$ & $(0.005)$ \\
Constant & $0.675^{* * *}$ & $0.692^{* * *}$ & $0.651^{* * *}$ & $0.664^{* * *}$ \\
& $(0.004)$ & $(0.005)$ & $(0.003)$ & $(0.004)$ \\
\hline Fixed effects & HS and Month & HS and Month & HS $\times$ Month & HS $\times$ Month \\
\hline \multirow{3}{*}{ Sample } & & Thick-trade & & Thick-trade \\
\hline Observations & Full & Products & Full & Products \\
Adjusted R-squared & 310,041 & 117,000 & 310,041 & 117,000 \\
\hline \hline
\end{tabular}

(4) 


\section{Table 7: Identifying the mechanisms (Chinese firms): Government Intervention or consumer sentiment?}

(1)

\begin{tabular}{|c|c|c|c|}
\hline & (1) & (2) & (3) \\
\hline & & Variable: $\mathrm{CA}$ & \\
\hline Fraction_Japan_Exports & $-33.968 *$ & $-26.080 *$ & $-27.765^{*}$ \\
\hline & $(17.548)$ & $(15.774)$ & $(15.840)$ \\
\hline Fraction_Japan_Exports $\times$ Drugs_and_Food & 55.122 & & 68.130 \\
\hline & $(63.993)$ & & $(65.666)$ \\
\hline Fraction_Japan_Exports $\times$ Consumer_Intensity & & -31.015 & -33.846 \\
\hline & & $(23.995)$ & $(23.946)$ \\
\hline Consumer_Intensity & & -0.218 & -0.222 \\
\hline & & $(0.740)$ & $(0.738)$ \\
\hline Fraction_Japan_Exports $\times$ Y2010 & 19.693 & 38.727 & 41.910 \\
\hline & $(17.436)$ & $(28.083)$ & $(27.896)$ \\
\hline Fraction_Other_Exports & $6.750 * *$ & $6.348 * *$ & $6.142 *$ \\
\hline & $(3.073)$ & $(3.121)$ & $(3.169)$ \\
\hline Log(TotalAssets) & $1.151 * * *$ & $1.168 * * *$ & $1.149 * * *$ \\
\hline & $(0.320)$ & $(0.321)$ & $(0.321)$ \\
\hline $\log (1+$ Tobin's Q) & 0.776 & 0.955 & 0.806 \\
\hline & $(1.095)$ & $(1.085)$ & $(1.095)$ \\
\hline Leverage & -0.093 & -0.106 & -0.096 \\
\hline & $(0.096)$ & $(0.095)$ & $(0.096)$ \\
\hline Constant & $-27.389 * * *$ & $-27.263 * * *$ & $-27.294 * * *$ \\
\hline & $(7.626)$ & $(7.631)$ & $(7.636)$ \\
\hline Fixed Effects & & ustry $\times$ Year & \\
\hline Number of Observations & 2,059 & 2,059 & 2,059 \\
\hline R-squared & 0.177 & 0.176 & 0.177 \\
\hline
\end{tabular}

Notes: Dependent variable in all columns is CAR Pooled, for the sample of Japanese listed firms, which is equal to CAR_Textbook for year $=2005$, and CAR_Senkaku for year $=2010$, and CAR_Textbook is the cumulative abnormal return during the Textbook Event (April 5, 2005 to April 28, 2005), and CAR_Senkaku is the cumulative abnormal return during the Senkaku Event (September 7, 2010 to October 29, 2010); Fraction_Japan_Exports is the ratio of total exports to Japan to total sales of each Chinese firm; Drugs_and_Food is a dummy variable that is equal to 1 for Chinese firms in Foods, Drugs, or Agriculture; Drugs_and_Food is a dummy denoting whether the Chinese firm is in the following industries: Foods, Drugs, and Agriculture; Consumer Intensity is a dummy variable that is equal to 1 if the firm mainly produces consumer-oriented products; Fraction_Others_Exports is the ratio of exports to all foreign countries other than Japan to total sales, for the sample of Chinese firms; $\log ($ TotalAssets) is the $\log$ of total assets of the firm; $\log (1+$ Tobin's $Q)$ is the $\log$ value of one plus Tobin's $\mathrm{Q}$; Leverage is the ratio of total liabilities to total assets. Fixed effects are at the 2-digit SIC level. In all cases, abnormal return is estimated using a standard Fama-French three-factor model using $[-150,-30]$ trading days as the estimation window. Robust standard errors are in parentheses. Robust standard errors, clustered at the firm level, are in parentheses. *, **, and *** indicate significance at the $10 \%, 5 \%$, and $1 \%$ level, respectively. 
Table 8: Investor sentiment and stock returns: Japanese firms

\begin{tabular}{|c|c|c|c|c|c|}
\hline & (1) & (2) & (3) & (4) & $(5)$ \\
\hline & \multicolumn{5}{|c|}{ Dependent Variable: CAR_Pooled } \\
\hline Fraction_China_Sales & $\begin{array}{l}-4.531 * \\
(2.437)\end{array}$ & $\begin{array}{l}-4.667 * \\
(2.451)\end{array}$ & $\begin{array}{l}-4.619 * \\
(2.446)\end{array}$ & $\begin{array}{l}-4.725 * \\
(2.427)\end{array}$ & $\begin{array}{c}-5.224 * * \\
(2.385)\end{array}$ \\
\hline Fraction_China_Sales $\times$ Fraction_Indiv_Japan & $\begin{array}{c}-162.443 * * * \\
(32.709)\end{array}$ & & & & \\
\hline Fraction_indiv & $\begin{array}{c}8.379 \\
(9.894)\end{array}$ & & & & \\
\hline Fraction_Other_Sales & $\begin{array}{c}0.594 \\
(1.782)\end{array}$ & $\begin{array}{c}0.815 \\
(1.802)\end{array}$ & $\begin{array}{c}0.709 \\
(1.812)\end{array}$ & $\begin{array}{c}0.454 \\
(1.788)\end{array}$ & $\begin{array}{c}0.442 \\
(1.788)\end{array}$ \\
\hline $\log ($ TotalAssets $)$ & $\begin{array}{l}-0.153 \\
(0.178)\end{array}$ & $\begin{array}{l}-0.213 \\
(0.173)\end{array}$ & $\begin{array}{l}-0.185 \\
(0.177)\end{array}$ & $\begin{array}{l}-0.144 \\
(0.177)\end{array}$ & $\begin{array}{c}-0.121 \\
(0.176)\end{array}$ \\
\hline $\log (1+$ Tobin's Q) & $\begin{array}{c}-2.329 * * * \\
(0.830)\end{array}$ & $\begin{array}{c}-2.138 * * * \\
(0.817)\end{array}$ & $\begin{array}{c}-2.243 * * * \\
(0.820)\end{array}$ & $\begin{array}{c}-2.379 * * * \\
(0.830)\end{array}$ & $\begin{array}{c}-2.479 * * * \\
(0.829)\end{array}$ \\
\hline Leverage & $\begin{array}{l}-1.642 \\
(1.315)\end{array}$ & $\begin{array}{l}-1.600 \\
(1.310)\end{array}$ & $\begin{array}{l}-1.567 \\
(1.311)\end{array}$ & $\begin{array}{l}-1.585 \\
(1.314)\end{array}$ & $\begin{array}{l}-1.577 \\
(1.325)\end{array}$ \\
\hline Fraction_China_Sales $\times$ Y 2010 & $\begin{array}{c}-11.521 * * \\
(4.956)\end{array}$ & $\begin{array}{c}-11.291 * * \\
(4.860)\end{array}$ & $\begin{array}{c}-11.407 * * \\
(4.849)\end{array}$ & $\begin{array}{c}-11.450 * * \\
(4.838)\end{array}$ & $\begin{array}{c}-11.564^{* *} \\
(4.881)\end{array}$ \\
\hline Fraction_China_Sales $\times$ I(Fraction_Indiv_Japan $>1)$ & & $\begin{array}{c}-35.265 * * * \\
(8.160)\end{array}$ & & & \\
\hline I(Fraction_Indiv_Japan $>1)$ & & $\begin{array}{c}0.243 \\
(1.715)\end{array}$ & & & \\
\hline Fraction_China_Sales $\times$ I(Fraction_Indiv_Japan $>5)$ & & & $\begin{array}{c}-36.094 * * * \\
(8.150)\end{array}$ & & \\
\hline I(Fraction_Indiv_Japan $>5)$ & & & $\begin{array}{c}1.046 \\
(1.806)\end{array}$ & & \\
\hline Fraction_China_Sales $\times$ I(Fraction_Indiv_Japan 10) & & & & $\begin{array}{c}-36.805 * * * \\
(8.307)\end{array}$ & \\
\hline I(Fraction_Indiv_Japan $>10)$ & & & & $\begin{array}{c}2.138 \\
(2.027)\end{array}$ & \\
\hline Fraction_China_Sales $\times$ I $($ Fraction_Indiv_Japan $>20)$ & & & & & $-35.090 * * *$ \\
\hline
\end{tabular}


Table 8: Investor sentiment and stock returns: Japanese firms (continued)

I(Fraction_Indiv_Japan $>20)$

Constant 0.464

$(1.984)$

\begin{tabular}{|c|c|c|c|c|c|}
\hline & $(2.021)$ & $(1.984)$ & $(2.011)$ & $(2.011)$ & $(2.007)$ \\
\hline Fixed Effects & \multicolumn{5}{|c|}{ Industry $\times$ Year } \\
\hline Number of Observations & 1,678 & 1,678 & 1,678 & 1,678 & 1,678 \\
\hline Adjusted R-squared & 0.077 & 0.079 & 0.078 & 0.077 & 0.074 \\
\hline
\end{tabular}

Notes: Dependent variable in all columns is $C A R$ Pooled, for the sample of Japanese listed firms, which is equal to $C A R$ Textbook for year $=2005$, and $C A R$ Senkaku for year $=2010$, and CAR_Textbook is the cumulative abnormal return during the Textbook Event (April 5, 2005 to April 28, 2005), and CAR_Senkaku is the cumulative abnormal return during the Senkaku Event (September 7, 2010 to October 29, 2010); Fraction_China_Sales is the ratio of sales in China to total sales for each Japanese firm; Fraction Indiv Japan is the ratio of individual ownership to all outstanding shares; I(Fraction Indiv Japan $>p$ ) is an indicator variable that is equal to 1 if individual ownership is larger than p\%; Fraction_Others_Sales is the ratio of sales in all the foreign countries other than China to total sales, for Japanese firms in the sample; Leverage is the ratio of total liabilities to total assets. Fixed effects are at the Nikkei Industry Code level (2-digit SIC equivalent). In all cases, abnormal return is estimated using a standard Fama-French three-factor model using $[-150,-30]$ trading days as the estimation window. Robust standard errors, clustered at the firm level, are in parentheses. $*, * *$, and $* * *$ indicate significance at the $10 \%, 5 \%$, and $1 \%$ level, respectively. 
Table 9A: The Long-term Effect on Profits: Japanese Firms

\begin{tabular}{|c|c|c|}
\hline Dependent variable: & $\begin{array}{c}(1) \\
\operatorname{ROA}(\mathrm{t}+1)\end{array}$ & $\begin{array}{c}(2) \\
\operatorname{ROA}(t+1)\end{array}$ \\
\hline I $($ year $\geq 2005) \times$ Fraction_China_Sales & $\begin{array}{l}-0.048 * * * \\
(0.018)\end{array}$ & $\begin{array}{c}-0.041 * * \\
(0.018)\end{array}$ \\
\hline Log(TotalAssets) & $\begin{array}{l}-0.039 * * * \\
(0.009)\end{array}$ & $\begin{array}{c}-0.042 * * * \\
(0.009)\end{array}$ \\
\hline $\mathrm{I}($ year $\geq 2005)$ & $\begin{array}{c}0.021 * * * \\
(0.003)\end{array}$ & $\begin{array}{l}-0.019 \\
(0.014)\end{array}$ \\
\hline Fraction_China_Sales & $\begin{array}{c}0.017 \\
(0.036)\end{array}$ & $\begin{array}{c}0.016 \\
(0.036)\end{array}$ \\
\hline $\mathrm{I}($ year $\geq 2005) \times \log ($ TotalAssets $)$ & & $\begin{array}{c}0.003 * * * \\
(0.001)\end{array}$ \\
\hline Constant & $\begin{array}{c}0.446 * * * \\
(0.102)\end{array}$ & $\begin{array}{c}0.476^{* * *} \\
(0.100)\end{array}$ \\
\hline Time Period & \multicolumn{2}{|c|}{$2002-2008$} \\
\hline Fixed Effects & $\begin{array}{l}\text { Firm \& } \\
\text { Year }\end{array}$ & $\begin{array}{l}\text { Firm \& } \\
\text { Year }\end{array}$ \\
\hline Number of Observations & 5,584 & 5,584 \\
\hline Adjusted R-squared & 0.489 & 0.490 \\
\hline
\end{tabular}

Notes: Dependent variable is $R O A$ in year $\mathrm{t}+1$. Fraction China Sales is the ratio of sales in China to total sales of the Japanese firms; $\log$ (TotalAssets) is the log of total assets of the firm; I(year $\geq 2005$ ) is an indicator variable that is equal to 1 for years after 2005. In all regressions, we also control for firm leverage. Robust standard errors, clustered at the firm level, are in parentheses. ${ }^{*}, * *$, and $* * *$ indicate significance at the $10 \%, 5 \%$, and $1 \%$ level, respectively. 
Table 9B: The Long-term Effect on profits: Chinese Firms

\begin{tabular}{|c|c|c|}
\hline Dependent variable: & $\begin{array}{c}(1) \\
\operatorname{ROA}(\mathrm{t}+1) \\
\end{array}$ & $\begin{array}{c}(2) \\
\operatorname{ROA}(\mathrm{t}+1) \\
\end{array}$ \\
\hline I(year $\geq 2005) \times$ Fraction_Japan_Exports & $\begin{array}{l}-0.132 \\
(0.103)\end{array}$ & $\begin{array}{l}-0.131 \\
(0.104)\end{array}$ \\
\hline $\mathrm{I}($ year $\geq 2005)$ & $\begin{array}{c}0.013^{* *} \\
(0.006)\end{array}$ & $\begin{array}{l}0.000 \\
(0.000)\end{array}$ \\
\hline Fraction_Japan_Exports & $\begin{array}{c}0.000 \\
(0.000)\end{array}$ & $\begin{array}{l}0.000 \\
(0.000)\end{array}$ \\
\hline Log(Assets) & $\begin{array}{c}-0.037 * * * \\
(0.006)\end{array}$ & $\begin{array}{c}-0.029 * * * \\
(0.007)\end{array}$ \\
\hline $\mathrm{I}($ year $\geq 2005) \times \log ($ TotalAssets $)$ & & $\begin{array}{c}-0.008^{* * *} \\
(0.003)\end{array}$ \\
\hline Constant & $\begin{array}{c}0.835^{* * *} \\
(0.133)\end{array}$ & $\begin{array}{c}0.663 * * * \\
(0.149) \\
\end{array}$ \\
\hline Time Period & \multicolumn{2}{|c|}{$2002-2008$} \\
\hline Fixed Effects & Firm \& Year & Firm \& Year \\
\hline Number of Observations & 5,331 & 5,331 \\
\hline Adjusted R-squared & 0.313 & 0.315 \\
\hline
\end{tabular}

Notes: Dependent variables is ROA in year $\mathrm{t}+1$; Fraction_Japan_Exports is the ratio of total exports to Japan to total sales of the Chinese firms; I(year $\geq 2005)$ is an indicator variable that is equal to 1 for years after 2005; $\log$ (TotalAssets) is the $\log$ of total assets of the firm. In all regressions, we control for firm leverage. Robust standard errors, clustered at the firm level, are in parentheses. *, **, and $* * *$ indicate significance at the $10 \%, 5 \%$, and $1 \%$ level, respectively. 


\section{Appendix A: Sino-Japanese economic and political relations}

China and Japan have had a unique relationship spanning over a thousand years. Japan imported Chinese characters along with other advanced skills as early as 60 A.D., and indeed China was often the source of new technologies and ideas for Japan. The Japanese have experienced eras of deep Chinese influence - when Chinese culture became a model for the Japanese - alternating with more independent periods. In the late nineteenth century, however, after the Edo era of inward-looking Japanese culture that reduced foreign influence in general, the country turned to study advanced technologies and political structures from Western nations, further untethering it from Chinese influence.

Concurrent with this shift away from China, a rapidly industrializing and militarized Japan confronted China in two Sino-Japan Wars (1894 - 1895 and 1937 - 1945), including the infamous Nanjing Massacre of 1937. This was part of a longer chapter of Western colonization in Chinese history that followed the Qing dynasty, tellingly referred to as the "100 years of humiliation.” Following World War II, Japan became an American ally, going under the security umbrella of the United States. Relations between China and Japan were cut off until after Nixon's 1972 trip to China, which was followed seven months later by a visit from Japanese Prime Minister Kakuei Tanaka, who began the process of re-establishing diplomatic relations.

During the 1970s and 1980s, China remained relatively unimportant as a trade partner for Japan, sharing less than 4 percent of Japan's trade volume (import + export); by comparison the U.S. accounted for 20 percent of Japanese trade. In the 1990s, China's share of Japanese trade grew rapidly as economic reforms took hold; It surpassed the U.S. as Japan's largest trade partner in 2006 and by 2009 accounted for 25 percent of Japanese trade volume, compared to 14 
percent for the U.S. ${ }^{23}$ For China, Japan is its second-largest trade partner ( $\$ 298$ billion in 2009) after the U.S. (\$385 billion). ${ }^{24}$ Economic ties have also been strengthened through investment channels. According to the 2009 - 2010 edition of "Chûgoku Shinshutsu Kigyô Ichiran: Jôjô Kaisha Hen (Almanac of Companies Doing Business in China: Listed Firms Volume)," over 1,800 Japanese listed firms (out of about 3,000) have over 6,300 Chinese subsidiaries. ${ }^{25}$

On the other hand, the long history of close relations has often been characterized by hostilities. Each December, Japan's Cabinet Office conducts an opinion survey that includes the question, "Do you feel China is friendly or unfriendly?" The results indicate that in the 1970s and early 1980s, Japanese sentiment toward China was largely favorable: about 75 percent of respondents answered "friendly". This period is often described as an era of "Ping-Pong Diplomacy" or "Panda Diplomacy" - China was regarded by Japanese as a benign presence. A worsening of Japanese sentiment toward China occurred only in 1989, the year of the Tian'An Men Square event, followed by a further deterioration in $2004-2005$ and 2010, coincident with the two cases we describe in further detail below: In 2005, only 32 percent of respondents described China as friendly, and by 2010, the figure had dropped to 20 percent.

A 2005 survey on attitudes in both countries, conducted by Genron (a Japanese Not-forProfit Organization), the China Daily, and Beijing University provides an indication of the depths of these unfriendly sentiments. Among Chinese respondents, the most common association with "Japan" was "Nanjing Massacre" and 60 percent of respondents listed Militarism as the dominant political ideology of Japan (Kudô 2005). Yet the survey also

\footnotetext{
${ }^{23}$ Japanese Customs data, http://www.customs.go.jp/toukei/suii/html/time.htm

${ }^{24}$ The U.S. - China Business Council data, http://www.uschina.org/statistics/tradetable.html

${ }^{25}$ The same almanac for unlisted Japanese firms (2007 - 2008 Edition) shows 4,700 Japanese unlisted firms have over 8,400 Chinese subsidiaries.
} 
highlighted the strength of economic ties between the two countries - after "Nanjing Massacre," the second most common association with "Japan" amongst surveyed Chinese was "Electronics" and the second most common characteristic used to describe Japanese character was "diligence" (ranked just behind "cruel and likes to go to war"). 


\section{Appendix Table 1: Investor sentiment and stock returns: Chinese firms}

\begin{tabular}{|c|c|c|}
\hline & (1) & (2) \\
\hline & \multicolumn{2}{|c|}{ Dependent variable: CAR_Pooled } \\
\hline \multirow[t]{2}{*}{ Fraction_Japan_Exports } & 17.231 & 48.642 \\
\hline & $(217.029)$ & $(242.387)$ \\
\hline \multirow[t]{2}{*}{ Fraction_Japan_Exports $\times$ Drugs_and_Food } & & 63.193 \\
\hline & & $(68.985)$ \\
\hline \multirow[t]{2}{*}{ Drugs_and_Food } & & $4.408 * *$ \\
\hline & & $(1.854)$ \\
\hline \multirow[t]{2}{*}{ Fraction_Japan_Exports $\times$ Consumer_Intensity } & & -35.893 \\
\hline & & $(28.812)$ \\
\hline \multirow[t]{2}{*}{ Consumer_Intensity } & & -0.189 \\
\hline & & $(0.739)$ \\
\hline \multirow[t]{2}{*}{ Fraction_Japan_Exports $\times$ Fraction_Indiv_China } & -50.369 & -77.079 \\
\hline & $(226.746)$ & $(246.043)$ \\
\hline \multirow[t]{2}{*}{ Fraction_Indiv_China } & 1.259 & 1.313 \\
\hline & $(1.923)$ & $(1.927)$ \\
\hline \multirow[t]{2}{*}{ Fraction_Others_Exports } & $0.069 * *$ & $0.061^{*}$ \\
\hline & $(0.031)$ & $(0.033)$ \\
\hline \multirow[t]{2}{*}{ Log(Total Assets) } & $1.247 * * *$ & $1.227 * * *$ \\
\hline & $(0.340)$ & $(0.341)$ \\
\hline \multirow[t]{2}{*}{ Log(1+Tobin’s Q) } & 1.018 & 0.890 \\
\hline & $(1.094)$ & $(1.104)$ \\
\hline \multirow[t]{2}{*}{ Leverage } & -0.108 & -0.099 \\
\hline & $(0.096)$ & $(0.096)$ \\
\hline \multirow[t]{2}{*}{ Y2010 } & 0.000 & 0.000 \\
\hline & $(0.000)$ & $(0.000)$ \\
\hline \multirow[t]{2}{*}{ Fraction_Japan_Exports $\times$ Y 2010} & 5.674 & 23.008 \\
\hline & $(59.254)$ & $(56.593)$ \\
\hline \multirow[t]{2}{*}{ Constant } & $-30.130 * * *$ & $-30.132 * * *$ \\
\hline & $(8.707)$ & $(8.700)$ \\
\hline \multicolumn{3}{|l|}{ Fixed Effects } \\
\hline Number of Observations & 2,059 & 2,059 \\
\hline Adjusted R-squared & 0.175 & 0.176 \\
\hline
\end{tabular}

Notes: Dependent variable in all columns is CAR_Pooled, for the sample of Chinese listed firms, which is equal to CAR_Textbook for year $=2005$, and CAR_Senkaku for year $=2010$, and CAR_Textbook is the cumulative abnormal return during the Textbook Event (April 5, 2005 to April 28, 2005), and CAR_Senkaku is the cumulative abnormal return during the Senkaku Event (Sept 7, 2010 to Oct 29, 2010); Fraction_Japan_Exports is the ratio of total exports to Japan to total sales of each Chinese firm; Fraction_Others_Exports is the ratio of exports to all foreign countries other than Japan to total sales, for the sample of Chinese firms; Drugs_and_Food is a dummy denoting whether the Chinese firm is in the following industries: Foods, Drugs, and Agriculture; Fraction_Indiv_China is the ratio of individual ownership to total outstanding shares; Consumer_Intensity is a dummy variable denoting firms mainly producing consumer-oriented products; Leverage is the ratio of total liabilities to total assets. Fixed effects are at the 2-digit SIC level. In all cases, abnormal return is estimated using a standard Fama-French three-factor model using $[-150,-30]$ trading days as the estimation window. Robust standard errors, clustered at the firm level, are in parentheses. *, $* *$, and $* * *$ indicate significance at the $10 \%, 5 \%$, and $1 \%$ level, respectively. 